Pontifícia Universidade Católica $_{\text {a }}$

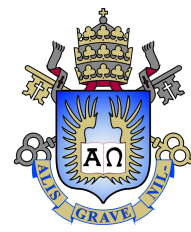

Marcelo Gomes de Souza

Inversão Sísmica Acústica Determinística utilizando Redes Neurais Artificiais

Dissertação de Mestrado

Dissertação apresentada como requisito parcial para obtenção do grau de Mestre pelo Programa de Pós-graduação em Informática do Departamento de Informática do Centro Técnico Científico da PUC-Rio.

Orientador: Prof. Marcelo Gattass 


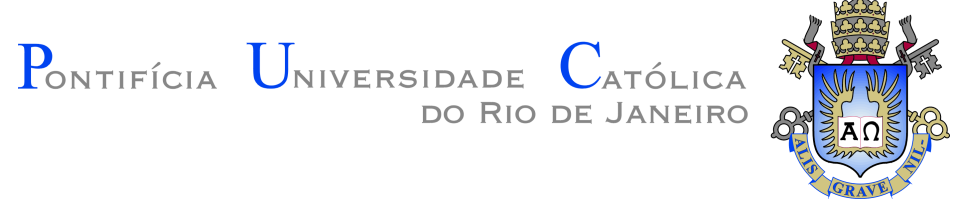

Marcelo Gomes de Souza

\section{Inversão Sísmica Acústica Determinística utilizando Redes Neurais Artificiais}

Dissertação apresentada como requisito parcial para obtenção do grau de Mestre pelo Programa de Pós-graduação em Informática do Departamento de Informática do Centro Técnico Científico da PUC-Rio. Aprovada pela Comissão Examinadora abaixo assinada.

Prof. Hélio Côrtes Vieira Lopes Departamento de Informática - PUC-Rio

Profa. Marley Vellasco

Departamento de Engenharia Elétrica - PUC-Rio

Prof. Márcio da Silveira Carvalho

Coordenador Setorial do Centro Técnico Científico - PUC-Rio 
Todos os direitos reservados. É proibida a reprodução total ou parcial do trabalho sem autorização da universidade, do autor e do orientador.

\section{Marcelo Gomes de Souza}

Graduou-se em Engenharia de Computação pela Pontifícia Universidade Católica do Rio de Janeiro no ano 2000, desde então trabalhou nas indústrias de Eletrônica e Óleo e Gás, sempre em projetos envolvendo computação científica e aprendizado de máquina.

Ficha Catalográfica

Souza, Marcelo Gomes de

Inversão Sísmica Acústica Determinística utilizando Redes Neurais Artificiais / Marcelo Gomes de Souza ; orientador: Marcelo Gattass. - 2018.

69 f. : il. color. ; $30 \mathrm{~cm}$

Dissertação (Mestrado)-Pontifícia Universidade Católica do Rio de Janeiro, Departamento de Informática, 2018.

Inclui bibliografia

1. Informática - Teses. 2. Inversão Sísmica; 3. Aprendizado de Máquina; 4. Redes Neurais; 5. Caracterização de Reservatórios; I. Gattass, Marcelo II. Pontifícia Universidade Católica do Rio de Janeiro. Departamento de Informática. III. Título. 


\section{Agradecimentos}

Agradeço ao meu orientador prof. Marcelo Gattass, que mesmo depois de eu estar por quase duas décadas afastado da academia acreditou no tema do meu trabalho, assim como na minha capacidade de realizá-lo.

Agradeço também à minha empresa, Halliburton, por acreditar que o conhecimento adquirido durante o curso seria muito valioso para o meu crescimento pessoal e profissional.

Agradeço à CAPES pelo apoio financeiro e à PUC-Rio pela bolsa de isenção de mensalidades do mestrado.

Agradeço também ao meu grande amigo Toni Pacheco por inúmeras dúvidas tiradas e pelas discussões de alto nível que fizemos para realização desse trabalho.

Agradeço à minha mulher Elysia e ao meu filho Theo, que me apoiaram, dando o suporte necessário para que conseguisse alcançar os objetivos do curso, assim como me permitindo dedicar várias horas que seriam originalmente passadas ao lado deles, e a eles eu dedico esse trabalho. 


\section{Resumo}

Souza, Marcelo Gomes de; Gattass, Marcelo. Inversão Sísmica Acústica Determinística utilizando Redes Neurais Artificiais. Rio de Janeiro, 2018. 69p. Dissertação de Mestrado - Departamento de Informática, Pontifícia Universidade Católica do Rio de Janeiro.

A inversão sísmica é o processo de transformar dados de Sísmica de Reflexão em valores quantitativos de propriedades petroelásticas das rochas. Esses valores, por sua vez, podem ser correlacionados com outras propriedades ajudando os geocientistas a fazer uma melhor interpretação que resulta numa boa caracterização de um reservatório de petróleo. Existem vários algoritmos tradicionais para Inversão Sísmica. Neste trabalho revisitamos a Inversão Colorida (Impedância Relativa), a Inversão Recursiva, a Inversão Limitada em Banda e a Inversão Baseada em Modelos. Todos esses quatro algoritmos são baseados em processamento digital de sinais e otimização. O presente trabalho busca reproduzir os resultados desses algoritmos através de uma metodologia simples e eficiente baseada em Redes Neurais e na pseudo-impedância.

Este trabalho apresenta uma implementação dos algoritmos propostos na metodologia e testa sua validade num dado sísmico público que tem uma inversão feita pelos métodos tradicionais.

\section{Palavras-chave}

Inversão Sísmica; Aprendizado de Máquina; Redes Neurais; Caracterização de Reservatórios; 


\section{Abstract}

Souza, Marcelo Gomes de; Gattass, Marcelo (Advisor). Deterministic Acoustic Seismic Inversion using Artificial Neural Networks. Rio de Janeiro, 2018. 69p. Dissertação de Mestrado Departamento de Informática, Pontifícia Universidade Católica do Rio de Janeiro.

Seismic inversion is the process of transforming Reflection Seismic data into quantitative values of petroleum rock properties. These values, in turn, can be correlated with other properties helping geoscientists to make a better interpretation that results in a good characterization of an oil reservoir.

There are several traditional algorithms for Seismic Inversion. In this work we revise Color Inversion (Relative Impedance), Recursive Inversion, Bandwidth Inversion and Model-Based Inversion. All four of these algorithms are based on digital signal processing and optimization. The present work seeks to reproduce the results of these algorithms through a simple and efficient methodology based on Neural Networks and pseudo-impedance.

This work presents an implementation of the algorithms proposed in the methodology and tests its validity in a public seismic data that has an inversion made by the traditional methods.

\section{Keywords}

Seismic Inversion; Machine Learning; Neural Networks; Reservoir Characterization; 


\section{Sumário}

1 Introdução $\quad 14$

2 Introdução ao Método Sísmico $\quad 16$

2.1 Sismologia de Reflexão 16

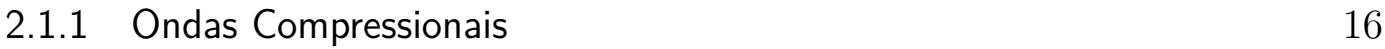

2.1.2 Ondas Cisalhantes 18

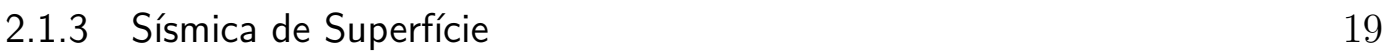

2.1.4 Resolução Sísmica e o Efeito Tuning 21

2.1.5 Impedância Acústica 22

2.1.6 Função de Refletividade da Terra 23

2.1.7 Impedância Acústica Relativa 23

2.2 A Wavelet 23

2.2.1 Modelo Convolucional 24

2.3 Lei de Faust 25

2.4 Relação de Gardner 25

3 Inversão Sísmica $\quad 27$

3.1 A Inversão Recursiva $\quad 27$

3.2 Inversão baseada em Modelos 29

3.2.1 Calibração do perfil sônico a partir dos check-shots 30

3.2.2 Seleção de um traço sísmico próximo ao poço 30

3.2.3 Análise de amarração de poços 31

3.2.4 Extração da wavelet a partir dos dados 31

3.2.5 Calibração da amplitude sísmica 31

3.2.6 Construção do modelo de baixa frequência 32

3.2.7 Parametrização do algoritmo de inversão 33

\begin{tabular}{ll}
3.2 .8 Inversão do volume & 34 \\
\hline
\end{tabular}

3.3 A Inversão Colorida 35

3.3.1 O Algoritmo 35

4 Trabalhos Relacionados $\quad 40$

5 Inversão acústica baseada em Redes Neurais Artificiais 48

5.1 O Dataset 49

5.1.1 Estratégia de treinamento e validação 51

5.2 Reprodução do algoritmo de Inversão Sísmica Colorida utilizando Redes Neurais Artificiais 52

5.3 Reprodução do algoritmo de Inversão Sísmica baseada em Modelos utilizando Redes Neurais Artificiais $\quad 55$

5.3.1 Modelagem da Rede Neural $\quad 56$

5.3.2 Os Atributos Sísmicos utilizados e os Resultados 57

5.3.2.1 A amplitude sísmica $\quad 58$

5.3.2.2 TWT - Two Wave Traveltime 59

5.3.2.3 VRMS - Modelo de Velocidade RMS 60 
$\begin{array}{lll}\text { 5.3.2.4 Conformance } & 61\end{array}$

5.3.2.5 Cl - A Inversão Colorida 63

5.3.3 O modelo final da Rede Neural 64

$\begin{array}{lll}6 & \text { Conclusões e trabalhos futuros } & 67\end{array}$

$\begin{array}{ll}\text { Referências bibliográficas } & 68\end{array}$ 


\section{Lista de figuras}

Figura 2.1 Onda P ou Primária, Longitudinal ou Compressionaldilatacional. Imagem extraída do site do Observatório Sismológico da UNB

Figura 2.2 Onda S, Secundária, Transversal ou Cisalhante: Não consegue se propagar no meio líquido. As vibrações de partículas seguem movimentos cisalhantes que são perpendiculares à direção de propagação da onda. Imagem extraída do site do Observatório Sismológico da UNB

Figura 2.3 Seção Sísmica: o eixo Y significa o tempo duplo da onda e o eixo X significa o traço da refletividade da terra. Preto significa amplitude máxima negativa e branco positiva

Figura 2.4 Diagrama da aquisição sísmica em terra e mar

Figura 2.5 Comprimento de Onda, Velocidade e Frequência em função da profundidade - Figura copiada de Brown, A. R., 2004 [1]

Figura 2.6 a. Impedância Acústica, b. Refletividade, c. Espectro de Amplitude da Refletividade, d. Wavelet, e. Traço Sísmico, f. Espectro de Amplitude da Wavelet, g. Espectro de Amplitude do Traço Sísmico - Figura adaptada de Oldenburg et al, 1983 [2]

Figura 3.1 Workflow de um processo de inversão baseada em modelo - As caixas mostradas em cinza são as que o proposto trabalho se destina a eliminar do processo

Figura 3.2 Exemplo de um modelo de baixa frequência realizado por krigagem dos dados de impedância acústica nos poços. Figura copiada de Leite, E. P., 2010 [3]

Figura 3.3 Otimização Global da Inversão baseada em Modelos

Figura 3.4 Quatro perfis de poços diferentes de um campo do Mar do Norte, representados em logaritmo da frequência, onde podemos claramente ver uma tendência linear, o que equivale a uma exponencial negativa e o coeficiente angular é exatamente o valor de $\beta$. Figura copiada de Lancaster et al. 2000 [4]

Figura 3.5 Filtro trapezoidal, onde a, b, c e d devem ser ajustados de forma a melhor se adaptar ao conteúdo de frequência da sísmica

Figura 3.6 Operador no domínio da frequência da inversão colorida Figura 3.7 Operador no domínio de tempo da inversão colorida

Figura 3.8 Resumo do fluxo completo da inversão Colorida - Figura copiada do Manual do software ARK CLS Seismic Coloured Inversion $\mathrm{V} 4.1$

Figura 4.1 Fluxograma do algoritmo proposto por Kuroda et al. contendo a rede neural para estimativa da porosidade e o algoritmo genético que objetiva encontrar o melhor conjunto de atributos. Figura copiada de Kuroda et al, 2016 [5] 
Figura 4.2 Resultados da estimativa de porosidade (em vermelho) quando comparadas aos dados reais em poços (em preto). Figura copiada de Kuroda et al, 2016 [5]

Figura 4.3 Modelagem da Rede Neural de uma camada escondida proposta por De Groot, utilizando uma janela deslizante sobre as amostras do traço sísmico. Figura copiada de De Groot, 1999 [6]

Figura 4.4 Definição de cada atributo nos neurônios de entrada com a janela deslizante, o tempo de trânsito da onda e a impedância acústica. Figura copiada de De Groot, 1999 [6]

Figura 4.5 Comparativo da predição da porosidade e do valor real realizado por De Groot. Figura copiada de De Groot, 1999 [6]

Figura 4.6 Resultado obtido da estimativa de impedância acústica utilizando uma inversão baseada em modelos. Figura copiada de Misra et al, 2011 [7]

Figura 4.7 Resultado obtido da estimativa da impedância acústica utilizando uma Rede Neural Probabilística. Figura copiada de Misra et al, 2011 [7]

Figura 5.1 Fluxo de uma inversão sísmica utilizando redes neurais artificiais proposto nesta dissertação

Figura 5.2 Localização no Mapa do Campo F3 no Mar do Norte 49

Figura 5.3 Localização dos poços no no Campo F3

Figura 5.4 Inlines 425 e 362 do dado de F3, utilizadas para treinamento e validação, respectivamente

Figura 5.5 Inline 425 de F3: à esquerda se encontra a sísmica original, e à direita o resultado da Inversão Colorida. A escala mostra a impedância Acústica Relativa em $\mathrm{Pa} \cdot \mathrm{s} / \mathrm{m}^{3}$

Figura 5.6 Topologia da rede neural artificial utilizada na inversão colorida

Figura 5.7 Inline 362 de F3 utilizado para validação do algoritmo, onde a primeira imagem é Inversão Sísmica realizada a partir do algoritmo de Inversão Colorida, e a segunda utilizando a Rede Neural

Figura 5.8 R2 Score (em azul) calculado traço a traço entre o resultado obtido pelo método tradicional e pelo método proposto na inline 362

Figura 5.9 Modelagem e atributos da Rede Neural Artificial

Figura 5.10 Inline 362: à esquerda o resultado da inversão baseada em modelos, e à direita o resultado do modelo utilizando apenas traços sísmicos como atributo

Figura 5.11 R2 Score traço a traço entre a inversão baseada em modelos e a inversão apenas com traços sísmicos como atributo

Figura 5.12 Inline 362: à esquerda o resultado da inversão baseada em modelos, e à direita o resultado do modelo utilizando traços sísmicos e tempo duplo de trânsito

Figura 5.13 R2 Score traço a traço entre a inversão baseada em modelos e a inversão apenas com traços sísmicos como atributo

Figura 5.14 Modelo de Velocidade RMS na Inline 425 
Figura 5.15 Inline 362: à esquerda o resultado da inversão baseada em modelos, e à direita o resultado do modelo utilizando traços sísmicos, tempo duplo de trânsito e modelo de velocidade RMS

Figura 5.16 R2 Score traço a traço entre a inversão baseada em modelos e a inversão baseada em Redes Neurais com traços sísmicos, tempo duplo de trânsito e modelo de velocidade RMS

Figura 5.17 Conformance entre os dois horizontes de interesse utilizados no trabalho

Figura 5.18 Inline 362: à esquerda o resultado da inversão baseada em modelos, e à direita o resultado do modelo utilizando traços sísmicos, tempo duplo de trânsito, modelo de velocidade RMS e Conformance

Figura 5.19 R2 Score traço a traço entre a inversão baseada em modelos e a inversão baseada em Redes Neurais com traços sísmicos, tempo duplo de trânsito, modelo de velocidade RMS e Conformance

Figura 5.20 Inline 362: à esquerda o resultado da inversão baseada em modelos, e à direita o resultado do modelo utilizando traços sísmicos, tempo duplo de trânsito, modelo de velocidade RMS, Conformance e Inversão Colorida

Figura 5.21 R2 Score traço a traço entre a inversão baseada em modelos e a inversão baseada em Redes Neurais com traços sísmicos, tempo duplo de trânsito, modelo de velocidade RMS, Conformance e Inversão Colorida

Figura 5.22 MSE por número de neurônios

Figura 5.23 Inline 362: à esquerda o resultado da inversão baseada em modelos, e à direita o resultado do modelo final utilizando traços sísmicos, tempo duplo de trânsito, modelo de velocidade RMS e Conformance

Figura 5.24 R2 Score traço a traço entre a inversão baseada em modelos e a inversão baseada em Redes Neurais com traços sísmicos, tempo duplo de trânsito, modelo de velocidade RMS e Conformance 


\section{Lista de tabelas}

Tabela 2.1 Constantes alpha da equação de Faust 2-14 em função das eras geológicas [8] 26

Tabela 2.2 Relação de Gardner para diferentes litologias [8] 26

Tabela 4.1 Conjunto de atributos sísmicos na escala de perfil usados no otimizador GA. O algoritmo para obtenção de cada um dos atributos sísmicos e sua interpretação pode ser encontrada em [9] 41

Tabela 4.2 Parâmetros usados no algoritmo de seleção de atributos baseado em GA

Tabela 4.3 Parâmetros usados no algoritmo de Redes Neurais para estimativa da porosidade 43

Tabela 5.1 Parâmetros de aquisição sísmica do dataset F3 50

Tabela 5.2 Poços disponíveis no Dado F3 com seus perfis disponíveis 51

Tabela 5.3 Hiper Parâmetros da Rede Neural utilizada para representar uma Inversão Sísmica Colorida 54

Tabela 5.4 Hiper-Parâmetros do modelo inicial da Rede Neural para reprodução do algoritmo de Inversão baseada em Modelos $\quad 57$

Tabela 5.5 Hiper-Parâmetros do modelo final da Rede Neural para reprodução do algoritmo de Inversão baseada em Modelos 
O sucesso é a soma de pequenos esforços repetidos dia após dia.

Robert Collier, 


\section{Introdução}

Nos dias de hoje, a escassez de reservas de petróleo em áreas de geologia mais simples e sobretudo a queda do preço do barril de petróleo a partir de 2014, fez a indústria de Óleo e Gás buscar maneiras de aproveitar melhor os campos já existentes e baratear o custo de exploração e produção dos novos. Nesse cenário, a modelagem sísmica computacional passou a ter um papel ainda mais significativo, uma vez que um poço exploratório no mar, por exemplo, pode custar dezenas ou até centenas de milhões de dólares. Assim a busca por métodos indiretos que integram diferentes fontes de dados foi intensificada. Esses métodos são muito valiosos, pois pode-se estimar as características da subsuperfície sem necessariamente perfurar novos poços [10], sendo a Inversão Sísmica um desses métodos indiretos.

A Inversão Sísmica é o processo de transformar dados de Sísmica de Reflexão em dados quantitativos de propriedades petroelásticas da rocha, sendo a principal a Impedância Acústica. Estas propriedades podem ser correlacionados com outras para uma melhor caracterização do reservatório de petróleo, ajudando os geocientistas a fazer uma melhor interpretação dos dados.

Existem vários algoritmos de otimização para esse o processo de inversão sísmica baseadas em processamento digital de sinais. Dentre esses podemos citar a Inversão Colorida (Impedância Relativa), a Inversão Recursiva, a Inversão Limitada em Banda, e a Inversão Baseada em Modelos. A complexidade e o esforço computacional desses algoritmos tem induzido a busca por processos mais simples de serem utilizados e mais eficientes computacionalmente.

As Redes Neurais Artificiais associadas a grande quantidade de dados rotulados atualmente disponíveis na indústria estão resolvendo muitos problemas que anteriormente requeriam modelos físicos e/ou matemáticos elaborados. A ideia de utilizar essas redes para resolver o problema de inversão sísmica é um passo natural da área. Ocorre, entretanto, que a obtenção de dados rotulados para este problema não é simples. Num levantamento sísmico de uma área que possui poucos ou nenhum poço exploratório o número de amostras rotuladas é muito pequeno para treinar uma rede neural artificial.

O presente trabalho busca investigar Redes Neurais Artificiais para 
reproduzir os resultados dos algoritmos tradicionais de inversão sísmica. A metodologia utiliza dados de pseudo-impedância como variáveis de saída para o treinamento, que no momento de predição são distribuídas por todo o volume sísmico 3D. Como entrada do algoritmo temos: dados da sísmica de reflexão, modelos de velocidade, modelos geológicos e mais qualquer outro atributo sísmico que possa que possa trazer alguma informação geológica ao algoritmo, facilitando com isso a busca por padrões necessários ao bom funcionamento deste.

Esta dissertação está dividida em 6 capítulos. O capítulo 2 apresenta os conceitos básicos de sísmica de forma a estabelecer uma notação e servir como referência para leitores pouco familiarizados com o método sísmico. O Capítulo 3 apresenta os trabalhos relacionados.

O Capitulo 4 discute o processo de inversão sísmica baseado em modelos, cujos resultados nosso modelo busca reproduzir. O Capítulo 5 apresenta o método proposto e os resultados que orientaram a escolhas dos parâmetros da rede neural. Finalmente o Capítulo 6 apresenta algumas conclusões e sugestões para trabalhos futuros.

Todos os códigos fonte dessa dissertação podem ser encontrados no repositório público Github no endereço eletrônico https://github.com/ marcelogsouza/mlpseismicinversion, de forma a tornar os resultados mais facilmente reprodutíveis. 


\section{2 \\ Introdução ao Método Sísmico}

Este capítulo apresenta alguns conceitos importantes para compreensão de um levantamento sísmico com dois objetivos: apresentar uma introdução ao leitor não familiarizado e o de estabelecer a notação e conceitos utilizados no método proposto.

\section{1}

\section{Sismologia de Reflexão}

A sismologia de reflexão ou somente sísmica de reflexão é o método de Exploração Geofísica que utiliza princípios de sismologia para estimar as propriedades e estruturas da terra através das ondas sísmicas geradas a partir de uma fonte e refletidas pelas interfaces no interior da terra. Existem diversos métodos de sísmica de reflexão, como a Sísmica de Superfície, a qual usaremos como base nesse trabalho e será explicada em 2.1.3 onde a fonte e os receptores encontram-se na superfície, e a chamada VSP ou Vertical Seismic Profiles, onde as fontes de vibração encontram-se em subsuperfície no interior de poços [10].

\subsection{1}

\section{Ondas Compressionais}

Existem diferentes formas que a energia pode se propagar por meio de vibrações em um meio físico. A mais comumente utilizada em métodos de Sismologia de Reflexão são as ondas compressionais.

Para ilustrar, vamos imaginar as vibrações causadas por uma fonte de energia em uma superfície. No exato momento do impacto, as partículas são deslocadas na direção do impacto da fonte, fazendo com que elas vibrem de forma a comprimir e expandir o material, conforme a Figura $2.1^{1}$.

\footnotetext{
${ }^{1}$ Imagem extraída do site do Observatório Sismológico da UNB - http: //164.41.28.233/obsis/index .php?option=com_content\&view=article\&id=55\& Itemid=66\&lang=pt-br - Acesso em 27 de fevereiro de 2018
} 


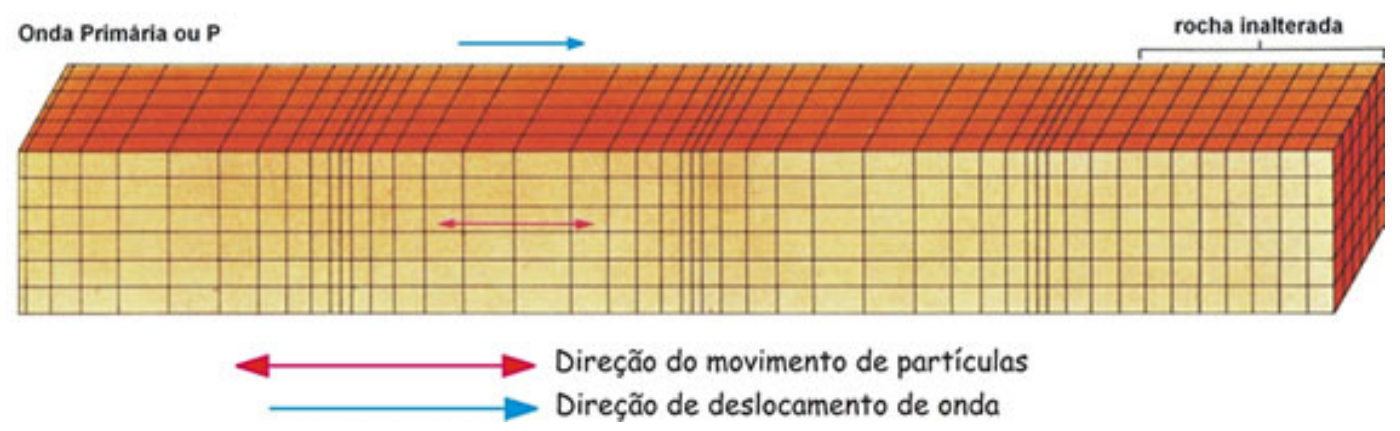

Figura 2.1: Onda P ou Primária, Longitudinal ou Compressional-dilatacional. Imagem extraída do site do Observatório Sismológico da UNB

A onda sonora é um exemplo de onda P. É mais rápida e consegue se propagar em todos os meios. As vibrações de partículas são paralelas à direção de propagação da onda e corresponde a sucessivas compressões e dilatações do meio por onde passam.

Para medir-se a velocidade de propagação da onda compressional na rocha, colocam-se transdutores em posições específicas a uma distância x, e medindo-se o tempo $t_{p}$ entre as excitações dos dois tradutores, podemos calcular a velocidade $V_{P}$ :

$$
V_{P}=\frac{x}{t_{p}}
$$

O estudo de ondas em meios elásticos contínuos estabelece a relação entre a velocidade e as constantes elásticas do material [11]:

$$
V_{P}=\sqrt{\frac{k+\frac{4}{3} \mu}{\rho}}
$$

$\mathrm{Ou}$

$$
V_{P}=\sqrt{\frac{E}{\rho}\left[\frac{1-\sigma}{(1-2 \sigma)(1+\sigma)}\right]}
$$

onde:

$k$ é o módulo de deformação volumétrica, ou módulo Bulk, que mede a capacidade da rocha de ser comprimida;

$\mu$ é o módulo de cisalhamento, que mede o poder de deformação sem variação do volume (no caso dos líquidos $\mu=0$ );

$\rho$ é a densidade do material;

$E$ é o módulo de Young que é um fator de proporcionalidade entre a tensão aplicada ao corpo e sua deformação;

$\sigma$ é o coeficiente de Poisson que é dado pela razão entre a contração transversal e a extensão longitudinal quando a barra é tensionada. 


\subsection{2}

\section{Ondas Cisalhantes}

Outra forma que a onda trafega no meio é conhecida como Onda Cisalhante, a qual trafega paralelamente à superfície de onde se originou o sinal sísmico (seja de forma natural como um abalo sísmico, seja de forma forma artificial como uma explosão numa aquisição sísmica), o que significa que as partículas da amostra são deslocadas perpendicularmente à direção de propagação no meio, conforme a Figura $2.2^{2}$.

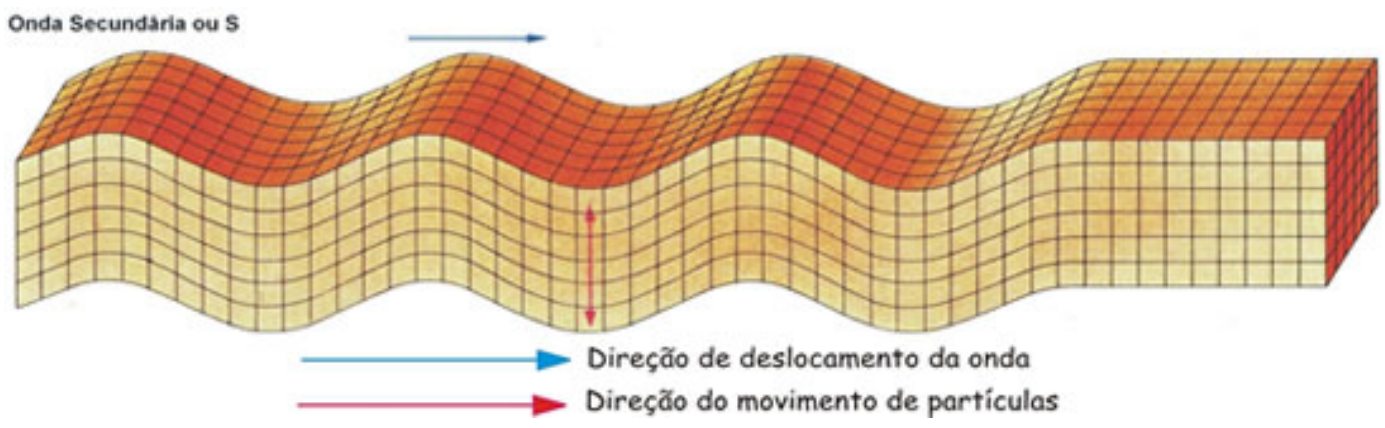

Figura 2.2: Onda S, Secundária, Transversal ou Cisalhante: Não consegue se propagar no meio líquido. As vibrações de partículas seguem movimentos cisalhantes que são perpendiculares à direção de propagação da onda. Imagem extraída do site do Observatório Sismológico da UNB

Da mesma forma que as Ondas Compressionais descritas em 2.1.1, a equação de velocidade de propagação da Onda S é:

$$
V_{P}=\frac{x}{t_{s}}
$$

Conhecidas as propriedades elásticas do material, pode-se verificar a relação [11]:

$\mathrm{Ou}$

$$
V_{S}=\sqrt{\frac{\mu}{\rho}}
$$

$$
V_{S}=\sqrt{\frac{E}{2 \rho(1+\sigma)}}
$$

Para gases e líquidos, onde $\mu=0$, vê-se que a $V_{S}=0$, o que significa que a Onda Cisalhante só se propaga em meios sólidos.

Das relações entre as ondas compressionais e as ondas cisalhantes, se as equações 2-2, 2-3, 2-5 e 2-6 forem combinadas temos [11]:

$$
\frac{V_{P}}{V_{S}}=\sqrt{\frac{k}{\mu}+\frac{4}{3}}
$$

${ }^{2}$ Imagem extraída do site do Observatório Sismológico da UNB - http: $/ / 164.41 .28 .233 /$ obsis $/$ index $\cdot$ php?option=com_content\&view=article\&id=55\& Itemid=66\&lang=pt-br - Acesso em 27 de fevereiro de 2018 
$\mathrm{Ou}$

$$
\frac{V_{P}}{V_{S}}=\sqrt{\frac{1-\rho}{1 / 2-\rho}}
$$

o fato de $k$ e $\mu$ serem números positivos indica que a relação $V_{P} / V_{S}>1$, ou seja as ondas compressionais sempre se propagam com maior velocidade do que as ondas cisalhantes através do mesmo material[10].

\subsection{3}

\section{Sísmica de Superfície}

A sísmica de reflexão é um método geofísico para imagear e caracterizar estruturas geológicas de subsuperfície, que se baseia no princípio que um abalo sísmico provocado na superfície a partir de uma fonte artificial vai se propagar para o interior da terra até encontrar uma interface delimitada por diferentes litologias ou propriedades físicas da rocha, fazendo com que parte da energia retorne à superfície e outra parte refrate até que encontre outras interfaces mais profundas da terra e também retornem à superfície posteriormente. Esta técnica se baseia no tempo decorrido entre a geração do pulso sísmico e a chegada dos impulsos refletidos e refratados nas estações receptoras, assim como suas amplitudes.

O resultado de um levantamento sísmico, após um longo processamento de alto custo computacional, é uma seção sísmica 2D ou um volume sísmico 3D, onde as estruturas podem ser interpretadas. Nessas seções ou volumes sísmicos o eixo vertical representa o tempo de propagação da onda da fonte até o receptor ( $T W T$ - Two Wave Traveltime), ou a profundidade, e os eixos horizontais a refletividade da terra, que será explicada em 2.1.6, com ângulo de incidência da onda igual a $0^{\circ}$, como podemos ver na Figura 2.3. 


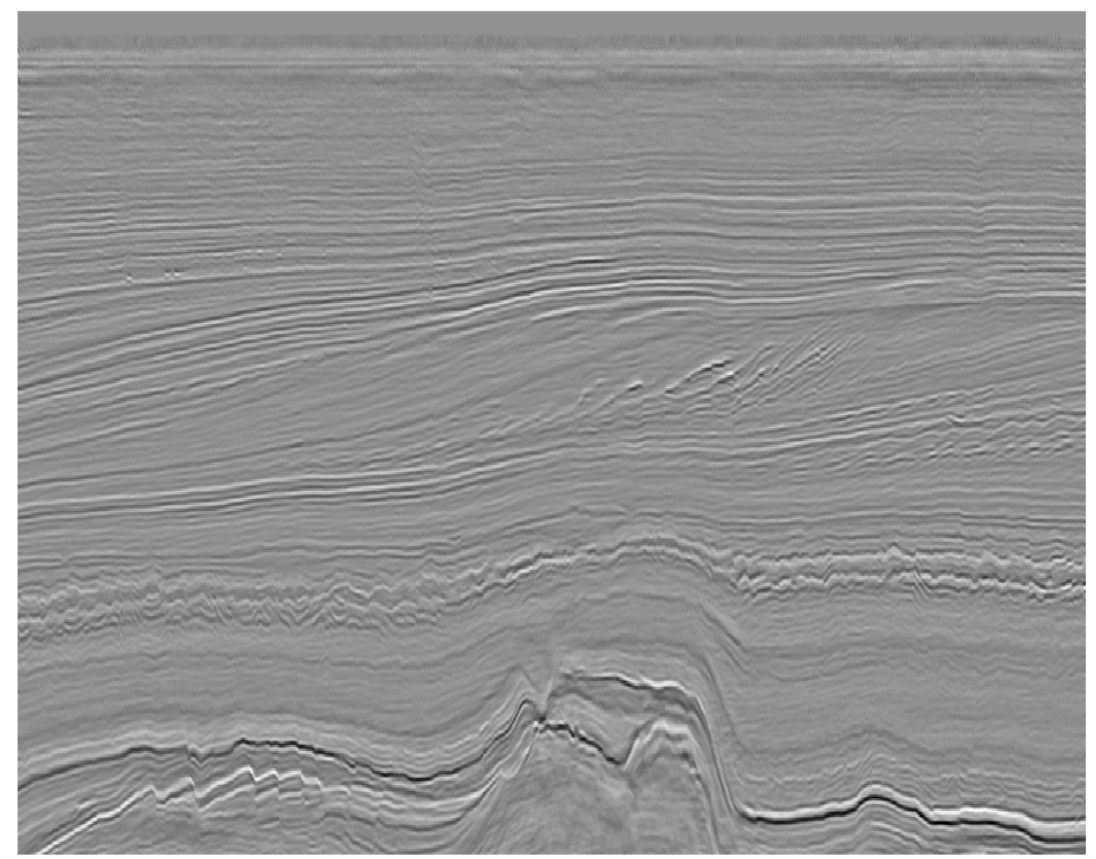

Figura 2.3: Seção Sísmica: o eixo Y significa o tempo duplo da onda e o eixo $\mathrm{X}$ significa o traço da refletividade da terra. Preto significa amplitude máxima negativa e branco positiva

O processo de levantamento se inicia a partir de um pulso sonoro para o interior da terra, utilizando-se no caso de aquisições terrestres dinamites ou vibradores em caminhões (vibroseis) e em aquisições marítimas canhões de ar comprimido (air guns) e estações receptoras, compostas de geofones em levantamentos terrestres, ou hidrofones em levantamentos marítimos, como pode ser visto no diagrama da Figura 2.4. Tanto os geofones, quanto hidrofones são sensores de alta fidelidade, sensíveis às pequenas vibrações, onde essas vibrações são transformadas em um sinal elétrico que são registradas em um sismógrafo.

O tempo que um sismógrafo armazena as informações a partir da geração do pulso, o chamado Record Length, depende da profundidade que está localizado o objetivo do levantamento. Isto é, quanto maior a profundidade de interesse, maior deve ser o tempo de registro. Um problema relativo a isso é que quanto mais profundo, o sinal retorna com apenas uma fração da energia que partiu (cerca de um milésimo do original), o que faz com que o receptor deva ser muito sensível a pequenas variações.

Como resultado de um levantamento sísmico temos o registro de um volume de amplitudes definido numa grade. Uma seção horizontal deste volume 
é chamada de Time Slice. As seções na direção do levantamento são chamadas de Inlines e as perpendiculares a ela de Crosslines.

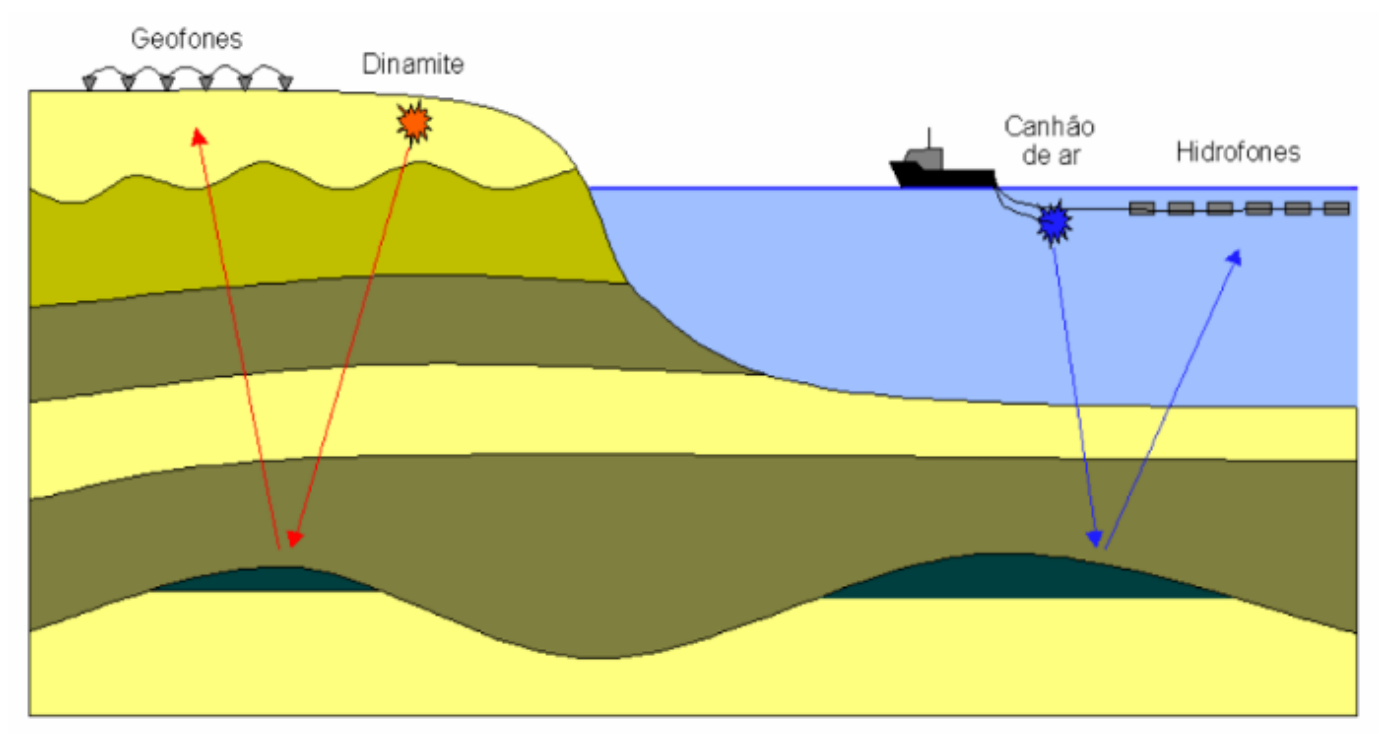

Figura 2.4: Diagrama da aquisição sísmica em terra e mar

\subsection{4}

\section{Resolução Sísmica e o Efeito Tuning}

O fenômeno de interferência construtiva/destrutiva das ondas sísmicas a partir de eventos ou reflexões próximas tem o nome de efeito Tuning (sem tradução em português). Em camadas menores que o limite da resolução de Rayleigh (um quarto do comprimento dominante da onda) as reflexões sofrem interferência e produzem um único evento, sendo indistinguíveis na imagem sísmica. A espessura mínima da camada que pode ser distinguida (espessura Tuning) é a seguinte:

onde

$$
Z=\frac{V_{I}}{2.8 f_{\max }}
$$

Z é a espessura de Tuning da camada, ou a resolução de Rayleigh;

$V_{I}$ é a velocidade intervalar na profundidade da camada;

$f_{\max }$ é a frequência de pico numa seção sísmica.

Outro ponto importante é que, segundo Sheriff [12], a velocidade sísmica em geral aumenta com a profundidade, visto que rochas mais antigas estão mais compactadas, e segundo a equação 2-9 um aumento na velocidade, aumenta também a espessura de Tuning. Além disso, as altas frequências são as mais atenuadas durante a propagação em profundidade. Esse efeito reduz a frequência máxima reforçando o aumento da espessura de Tuning para camadas mais profundas. Assim, na sísmica de superfície de modo geral, as camadas 
mais rasas são mais facilmente resolvidas do que as mais profundas. Podemos verificar qualitativamente essas propriedades na Figura 2.5 apresentada por Brown [1], onde com a profundidade o conteúdo de frequência diminui (linha azul), a velocidade aumenta (linha verde) e o comprimento de onda aumenta (linha vermelha).

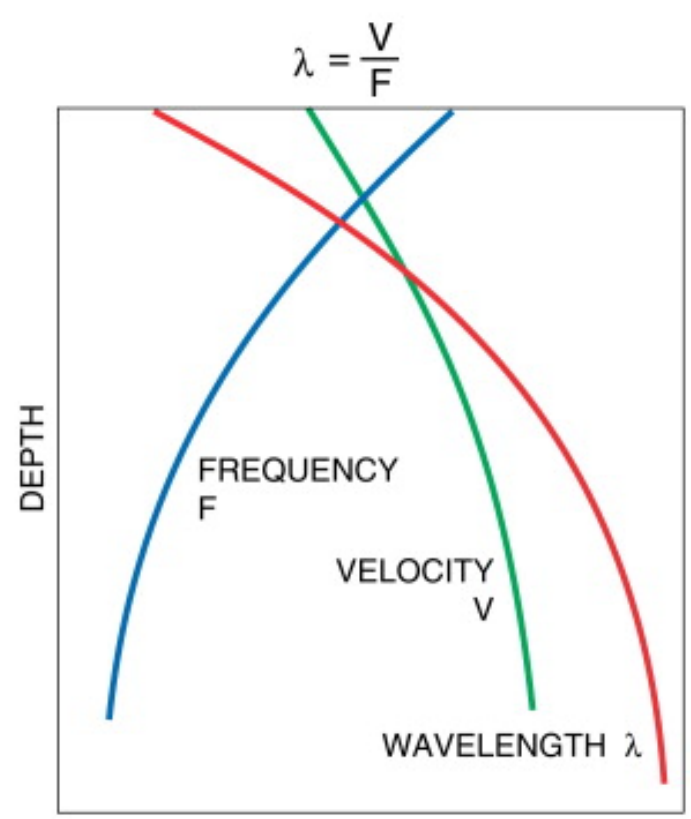

Figura 2.5: Comprimento de Onda, Velocidade e Frequência em função da profundidade - Figura copiada de Brown, A. R., 2004 [1]

\subsection{5}

\section{Impedância Acústica}

A Impedância Acústica é a resistência ou dificuldade que a onda acústica tem de trafegar por determinado material. Em termos matemáticos é o produto entre a velocidade $(V)$ da onda no material e a densidade $(\rho)$ do mesmo:

$$
Z=\rho V
$$

Uma consideração a fazer é que a velocidade é usualmente mais importante na equação que a densidade, pois uma variação no fluido de preenchimento (água, óleo ou gás em um arenito por exemplo) tem um efeito muito maior na velocidade de propagação do que na densidade do material.

A importância da Impedância Acústica é que apesar de ser uma propriedade acústica, pode ser correlacionada com propriedades petrofísicas da rocha. O presente trabalho tem o objetivo de discutir uma técnica capaz de calcular essa propriedade através de dados sísmicos correlacionados com informações de poços. 


\subsection{6}

\section{Função de Refletividade da Terra}

O coeficiente de reflexão ou Refletividade descrita é um conceito físico fundamental no método sísmico. Basicamente a refletividade pode ser entendida como um fator da quantidade de energia da onda propagada que é refletida quando encontra a uma mudança de Impedância Acústica. Em uma interface plana entre duas camadas elásticas espessas, homogêneas e isotrópicas, k e $\mathrm{k}+1$, a refletividade de uma onda que incide na direção normal das camadas é dada por[11]:

$$
r_{k}=\frac{Z_{k+1}-Z_{k}}{Z_{k+1}+Z_{k}}
$$

onde:

$r_{k}$ é o coeficiente de reflexão na camada $\mathrm{k}$;

$Z_{k}$ é a impedância acústica na camada k;

$Z_{k+1}$ é a impedância acústica na camada $\mathrm{k}+1$;

e a camada k está sobre a camada k+1.

\subsection{7}

\section{Impedância Acústica Relativa}

A impedância acústica relativa é uma medida simplificada da Impedância Acústica, essa última também chamada de Impedância Acústica Absoluta, onde a componente $\mathrm{DC}^{3}$ do sinal é removido, ou em outras palavras, as baixas frequências permanecem ausentes. É um atributo sísmico de muito valor, pois seu cálculo é muito mais simples que da Impedância Acústica Absoluta, pois como será visto em 3.3 não depende de modelagem geológica, preservando informação das variações da impedância entre as camadas.

\section{2}

\section{A Wavelet}

A Wavelet pode ser entendida como o pulso unidimensional de resposta a um estímulo causado por uma fonte, air-gun ou dinamite, e capturada por um receptor. Seus principais atributos são Amplitude, Frequência e Fase.

Na figura 2.6 adaptada de Oldenburg et al [2] pode-se observar o efeito da wavelet sobre um pulso sísmico da seguinte forma: Em 2.6a tem-se a impedância acústica da rocha; $2.6 \mathrm{~b}$ a função refletividade da terra, segundo a Equação 2-11; 2.6c o espectro de amplitude da refletividade, onde vemos

${ }^{3}$ DC - Direct Current em inglês ou Corrente Contínua em Português, termo adotado da disciplina de Eletricidade para definir quando um sinal tem uma componente constante no tempo. 
que não é limitada em banda uma vez que cobre todo o espectro (abscissa no gráfico); 2.6d a wavelet sísmica em domínio de tempo; 2.6e o traço sísmico que é gerado à partir da convolução da refletividade da terra pela wavelet; 2.6f o espectro de amplitude da wavelet sísmica, onde vemos que é limitada em banda, uma vez que só ocupa parte do espectro (abscissa no gráfico); e finalmente $2.6 \mathrm{~g}$, que é o espectro de amplitude do traço sísmico, que também é limitado em banda, mostrando que em termos matemáticos, a wavelet funciona como um filtro passa-banda, ou um envelope no espectro de amplitude.

Essa filtragem se dá por alguns efeitos:

- pela absorção da energia no meio físico, onde as altas frequências são as mais absorvidas;

- pela tecnologia do receptor, que não é capaz de capturar sinais $D C$, ou de muito baixas frequências;

- outro efeito importante é que a própria fonte sísmica não é uma fonte impulsiva, tendo espectro limitado em banda.
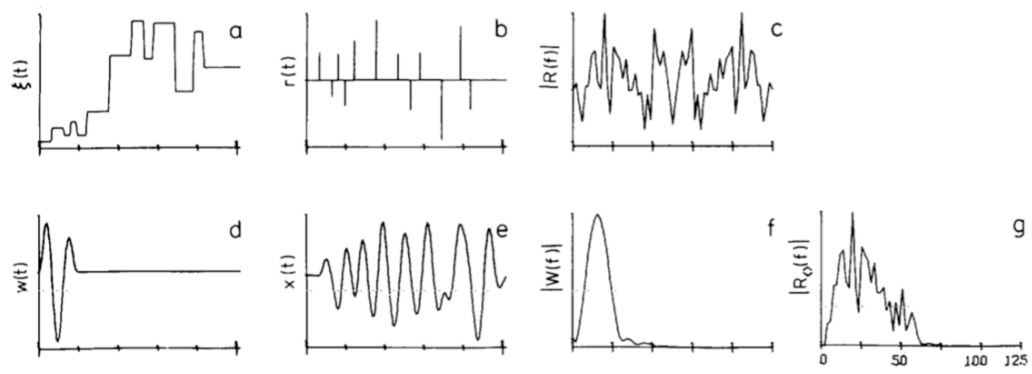

Figura 2.6: a. Impedância Acústica, b. Refletividade, c. Espectro de Amplitude da Refletividade, d. Wavelet, e. Traço Sísmico, f. Espectro de Amplitude da Wavelet, g. Espectro de Amplitude do Traço Sísmico - Figura adaptada de Oldenburg et al, 1983 [2]

\subsection{1}

\section{Modelo Convolucional}

O modelo unidimensional mais básico e comumente utilizado para representar matematicamente um traço sísmico é conhecido como modelo convolucional, que se baseia no princípio que um traço sísmico é a convolução da refletividade da terra com a função da fonte sísmica com a adição de um componente de ruído, segundo a equação [13]:

$$
s(t)=w(t) * r(t)+n(t)
$$

onde: 
$s(t)$ é o traço sísmico;

$w(t)$ é a função da wavelet sísmica;

$r(t)$ é a refletividade da terra;

$n(t)$ é um ruído aditivo;

* representa a operação de convolução.

Para uma representação ainda mais simples, remove-se o ruído $n(t)$ da equação, considerando-o nulo, assim a equação fica:

$$
s(t)=w(t) * r(t)
$$

Essa equação simplificada é utilizada em praticamente todos os softwares da indústria, não somente em fluxos de inversão, mas em outros fluxos como os descritos em 3.2.3 e 3.2.4.

O modelo convolucional representa uma Modelagem Sísmica Direta, e é o processo inverso à Inversão Sísmica, que será apresentado em 3 e consiste em criar um traço sísmico a partir de um perfil de Impedância Acústica.

\section{3}

\section{Lei de Faust}

Em contraste ao que foi apresentado na seção 2.1.1, onde as velocidades de propagação das ondas compressionais são calculadas a partir de relações empíricas das propriedades dos materiais, uma relação importante diz respeito ao efeito da profundidade sobre a velocidade de propagação. A essa relação dá-se o nome de lei de Faust [14], segundo a equação:

$$
v(z)=\alpha z^{\frac{1}{6}}
$$

onde:

$v$ é a velocidade compressional (em quilopés/s),

$z$ é a profundidade em pés,

$\alpha$ é uma constante que depende da era geológica.

A Tabela 2.1 apresenta valores de $\alpha$ da equação 2-14 para diferentes eras geológicas.

\section{4}

\section{Relação de Gardner}

Outra relação importante é conhecida como Relação de Gardner [15], que diz que a densidade tem uma relação não-linear com a velocidade, segundo a equação 2-15:

$$
\rho\left(v_{p}\right)=c v_{p}^{\frac{1}{4}}
$$




\begin{tabular}{ll}
\hline Era geológica & $\alpha$ \\
\hline Terciário & 2,190 \\
Eoceno & 2,332 \\
Cretáceo & 2,607 \\
Jurássico-Triássico & 2,823 \\
Permiano & 2,866 \\
Pensilvaniano & 3,047 \\
Mississipiano & 3,235 \\
Devoniano & 3,380 \\
Ordoviciano & 3,439 \\
\hline
\end{tabular}

Tabela 2.1: Constantes alpha da equação de Faust 2-14 em função das eras geológicas [8]

onde

$\rho$ é a densidade em $\mathrm{g} / \mathrm{cm}^{3}$,

$v_{p}$ é a velocidade da onda compressional $\mathrm{em} \mathrm{km} / \mathrm{s}$,

c é uma constante que depende do sistema de unidades e da litologia.

o expoente $\frac{1}{4}$ pode assumir outros valores dependendo da litologia conforme a tabela 2.2, porém Gardner [15] em seu artigo apresenta originalmente a expressão nessa forma.

Essa relação, assim como a Lei de Faust foi obtida empiricamente para diferentes tipos de litologia, como mostrado na tabela 2.2:

\begin{tabular}{lll}
\hline Litologia & Relação de Gardner & Validade para $v_{p} \mathrm{em} \mathrm{Km} / \mathrm{s}$ \\
\hline Geral & $\rho=1,74 v_{p}^{0,125}$ & $1,5 \rightarrow 9,0$ \\
Arenito & $\rho=1,75 v_{p}^{0,265}$ & $1,5 \rightarrow 5,0$ \\
Folhelho & $\rho=1,66 v_{p}^{0,261}$ & $1,5 \rightarrow 6,0$ \\
Calcária & $\rho=1,50 v_{p}^{0,225}$ & $3,5 \rightarrow 6,4$ \\
Dolomita & $\rho=1,74 v_{p}^{0,252}$ & $4,5 \rightarrow 7,1$ \\
Anidrita & $\rho=2,79 v_{p}^{0,160}$ & $4,6 \rightarrow 7,4$ \\
\hline
\end{tabular}

Tabela 2.2: Relação de Gardner para diferentes litologias [8] 


\section{3 \\ Inversão Sísmica}

A sísmica de reflexão ainda é utilizada até hoje como o principal método para delineação das estruturas geológicas de subsuperfície [13]. Porém, a reflexão sísmica contém informações que vão além da posição de um refletor, como introduzido em 2.1.6, pois os contrastes entre as impedâncias acústicas podem ser vistos como um refletor de maior ou menor amplitude e essas amplitudes podem ser correlacionadas com informações adquiridas no poço. A essas técnicas de correlação entre propriedades acústicas medidas em superfície e em subsuperfície dá-se o nome de Inversão Sísmica.

A Inversão Sísmica, como o próprio nome diz, pode ser considerada o processo inverso à Modelagem Sísmica Direta apresentada em 2.2.1 [16]. A Inversão Sísmica busca, a partir das medidas de superfície estimar as propriedades físicas de subsuperfície através de modelos físicos, como será apresentado em 3.1 e 3.2 [13], ou baseadas em Aprendizado de Máquina, como é o objetivo desse trabalho e é apresentado no capítulo 5.

Atualmente a maioria dos geofísicos prefere usar os dados de impedância acústica como principal fonte de dados para interpretação. A impedância representa o sinal simplificado quando comparado à resposta sísmica normal. Dados de impedância produzem estruturas mais precisas e detalhadas a partir da interpretação estratigráfica quando comparadas a utilização da amplitude sísmica. Outra vantagem da utilização da impedância acústica é a diminuição do efeito tuning, já que a espessura das camadas resolvidas com a impedância acústica são bem mais delgadas que as camadas de amplitude sísmicas [17].

A Inversão Sísmica é usada em diferentes disciplinas de Exploração e Produção e pode ser aplicada em um espectro amplo de escalas e níveis de complexidade como estimativas de saturação de fluidos, classificação de fácies litológicas e correlação de propriedades petrofísicas como porosidade e permeabilidade.

\section{1}

\section{A Inversão Recursiva}

O método mais simples de Inversão Sísmica é a Inversão Recursiva que se baseia nas seguintes premissas: (a) a terra consiste em uma sequência de 
camadas de planos paralelos de rochas com propriedades constantes, (b) o modelo convolucional é válido e (c) a impedância acústica na primeira amostra da refletividade é conhecida [13].

Essas premissas nos permite modelar a refletividade da terra como uma função esparsa que é diferente de zero apenas nas fronteiras das camadas litológicas. Essa função refletividades pode ser escrita por:

$$
r(t)=\sum_{k=1}^{N L} r_{k} \delta\left(t-\tau_{k}\right)
$$

onde $N L$ é o número total de camadas, $k$ é número da camada, $r_{k}$ é o coeficiente de reflexão entre duas camadas, $\tau_{k}$ é o tempo de trânsito duplo da camada $k$ à superfície e $\delta$ é o impulso unitário.

A impedância acústica na camada $k$ é definida:

$$
Z_{k}=V_{k} \rho_{k}
$$

onde $Z_{k}$ é a impedância acústica na camada $\mathrm{k}, V_{k}$ é a velocidade da onda compressional na camada $k, \rho_{k}$ é a densidade da camada $k$.

A partir da equação refletividade em função da impedância acústica na camada k, como mostrado na equação 2-11:

$$
r_{k}=\frac{Z_{k+1}-Z_{k}}{Z_{k+1}+Z_{k}}
$$

Reorganizando a equação, podemos estimar a impedância na camada $k+1$ em termos da refletividade e da impedância na camada $k$ :

$$
Z_{k+1}=Z_{k}\left(\frac{1+r_{k}}{1-r_{k}}\right)
$$

Expandindo-se a equação 3-4, em termos da impedância acústica na primeira camada e de todas as refletividades nas camadas anteriores, chegamos à seguinte equação recursiva:

$$
Z_{k+1}=Z_{1} \prod_{j=1}^{k}\left(\frac{1+r_{j}}{1-r_{j}}\right)
$$

que é a equação da inversão recursiva.

Para coeficientes de reflexão baixos $(\mathrm{r}<0.2)$, o resultado pode ser aproximado por:

$$
\ln \left(Z_{k+1}\right) \approx \ln \left(Z_{1}\right)+2 \sum_{j=1}^{k} r_{j}
$$

onde podemos observar na equação 3-6 que há uma relação quase linear entre a refletividade e o logaritmo da impedância acústica. 


\section{2}

\section{Inversão baseada em Modelos}

A Inversão baseada em Modelos é um algoritmo que é considerado o estado da arte para Inversão Sísmica, e no presente trabalho, vamos utilizála como Benchmark. O algoritmo se baseia em gerar dados sintéticos para um modelo e compará-los com dados observados. Se a correspondência entre os dados observados e sintéticos for aceitável, o modelo é considerado como solução final. Caso contrário o modelo é alterado, os sintéticos são recalculados e comparados novamente com os dados observados. Esse procedimento iterativo baseado na modelagem direta é repetido até que uma correspondência aceitável seja obtida entre os dados e o modelo sintético. Portanto, a Inversão baseada em Modelos é um processo de otimização onde se busca um modelo que melhor explique as observações. A adequação (fitness ou misfit) entre dados observados e sintéticos é utilizada como medida de aceitabilidade de um modelo da terra [16].

Segundo Ma [17], um típico fluxo de trabalho de inversão sísmica baseado em modelos deve seguir os seguintes passos:

(i) Calibração do perfil sônico a partir dos checkshots;

(ii) Seleção de um traço sísmico próximo ao poço;

(iii) Análise de amarração de poços;

(iv) Extração da wavelet a partir dos dados;

(v) Calibração da amplitude sísmica;

(vi) Construção do modelo de baixa frequência;

(vii) Parametrização do algoritmo de inversão;

(viii) Inversão do volume.

Cada etapa do fluxo é explicada a seguir. O mesmo fluxo é representado na figura ??, onde em cinza estão as etapas mais custosas em termos de trabalho humano e que a essa dissertação tem o objetivo de apresentar uma solução na qual esses passos não são necessários. 


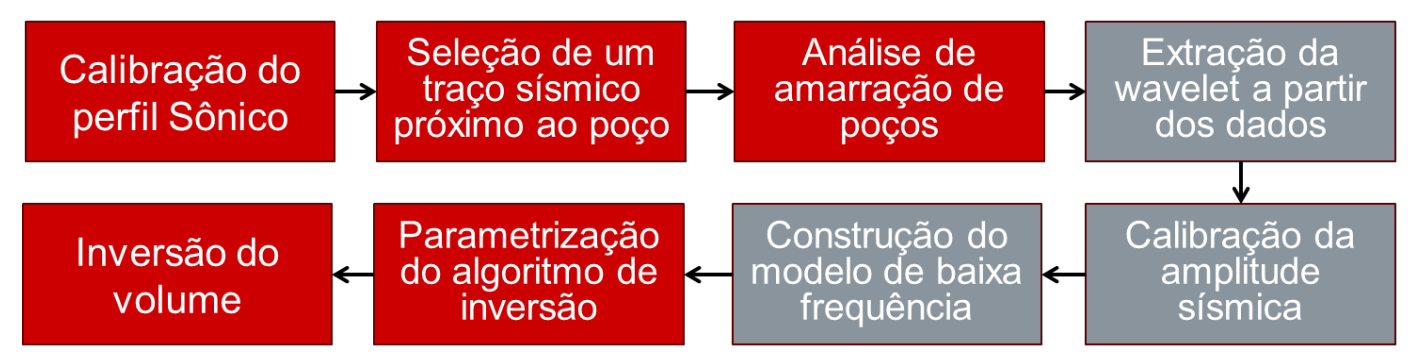

Figura 3.1: Workflow de um processo de inversão baseada em modelo - As caixas mostradas em cinza são as que o proposto trabalho se destina a eliminar do processo

\subsection{1}

\section{Calibração do perfil sônico a partir dos check-shots}

A calibração de um perfil de poços é um processo que faz o casamento do tempo associado a um perfil sônico com relação ao tempo de trânsito da onda sísmica a partir de um check-shot ${ }^{1}$. A calibração inicia-se a partir da diferença entre a integral do perfil sônico com o tempo de um check-shot. Esse valor de desvio deve ser aplicado ao perfil sônico de modo a ter uma curva de conversão tempo-profundidade compatível com os check-shots [17].

\subsection{2}

\section{Seleção de um traço sísmico próximo ao poço}

Um traço sísmico próximo ao poço deve ser selecionado para vários propósitos em um projeto de inversão sísmica. O mais importante deles é para criar um traço sísmico sintético, com o objetivo de amarrar os dados de poço e sísmica e assim estimar a wavelet que melhor se adapta ao dado, considerando-se o modelo convolucional.

Por uma série de razões, o traço mais próximo ao poço não necessariamente é a melhor escolha. Isso é causado principalmente porque na verdade as ondas sísmicas não trafegam como planos horizontais de uma fonte na supefície a um refletor em subsuperfície, e como a velocidade de propagação da onda normalmente aumenta com a profundidade, a tendência é que o processo de migração sísmica mova o ponto de melhor correlação para fora da trajetória do poço. Assim, o geofísico deve escolher o traço sísmico em torno do poço com melhor correlação possível (correlação de Pearson) entre o traço sintético gerado à partir do perfil poço segundo o modelo convolucional e o traço sísmico real [17].

\footnotetext{
${ }^{1}$ Tipo de dados símicos em poços que tem o objetivo de medir o tempo de trânsito de uma onda sísmica da superfície a uma profundidade conhecida.
} 


\subsection{3}

\section{Análise de amarração de poços}

A análise de amarração de poços se refere ao processo de comparar um traço sintético com o dado sísmico real, para que se possa estimar a relação entre os tempos de trânsito da onda e as profundidades dos eventos no perfil e a essa relação damos o nome de tabela tempo-profundidade. Para criar o traço sintético devemos utilizar o modelo convolucional e compará-lo ao traço real sísmico. Para quantificar a correspondência entre o traço sintético e o real, o coeficiente de correlação de Pearson é muitas vezes utilizado, onde um número superior a 0.7 indica uma boa amarração, e abaixo de 0.5 uma amarração bastante ruim.

A análise de amarração de poços deve ocorrer no intervalo da profundidade de interesse, normalmente a área do reservatório.Caso seja realizada em outra área e considerando-se a não-estacionariedade do sinal sísmico, não há garantia que o resultado na área de interessa seja bom.

\subsection{4}

\section{Extração da wavelet a partir dos dados}

A estimativa da wavelet por si só tem sido um campo de pesquisa por décadas. Apesar de muitas técnicas terem sido desenvolvidas, continua sendo um desafio, pois várias etapas do processo dependem de uma boa estimativa dela.

Existem vários algoritmos diferentes para a estimativa da wavelet, que podemos dividir em duas classes. A primeira é baseada na iteração e refinamento da Amarração de Poços, diminuindo progressivamente o coeficiente de correlação. A segunda classe denominada método estatístico, utiliza apenas dados sísmicos e parte do princípio que a refletividade é um ruído branco e das propriedades descritas em 2.2 , onde a wavelet é responsável pela limitação de banda do sinal sísmico. O problema dessa segunda técnica é que uma estimativa errada da fase da wavelet não apenas resulta em uma estimativa errada da espessura de uma camada, mas desloca esta verticalmente, introduzindo em erros na quantificação de uma reserva.

\subsection{5}

\section{Calibração da amplitude sísmica}

O valor da amplitude absoluta no dado sísmico é arbitrário e depende do processamento, onde cada fase modifica essa amplitude. Não é incomum que o mesmo dado processado por diferentes geofísicos de processamento levem a dados com amplitudes muito diferentes. Porém, deve-se manter constante 
a amplitude relativa entre os picos em um dado sísmico, pois esse dado será considerado pelo algoritmo de inversão como a representação aproximada da refletividade da terra a partir apenas de uma operação de escala (multiplicação por uma constante).

O cálculo dessa constante é o que se chama de calibração da amplitude sísmica, e o processo para o cálculo é o seguinte: constrói-se um traço sintético como mostrado em 3.2.3. A partir dele, o cálculo da amplitude $\mathrm{RMS}^{2}$ pode ser realizada tanto no traço sintético quanto no traço sísmico. Esses perfis são de baixa frequência (suaves) e contêm apenas valores positivos, e o valor médio da razão entre o traço sintético e o traço sísmico resulta em um fator pelo qual o dado sísmico deve ser multiplicado para que o dado se torne calibrado em amplitude.

\subsection{6}

\section{Construção do modelo de baixa frequência}

Um típico dado sísmico é limitado em banda, com frequências normalmente entre 10 e 80Hz. Com isso, apenas a partir do dado sísmico, a inversão não é capaz de recuperar as informações abaixo desse intervalo. Para que essa informação de baixa frequência seja então incorporada ao processo de inversão, possibilitando a reconstrução da impedância acústica absoluta da terra, outras fontes de dados devem ser utilizadas. Existem várias formas de se construir um modelo de baixa frequência. Um método comum e bastante utilizado na indústria é a interpolação e extrapolação dos perfis de poços entre horizontes interpretados. Essa interpolação pode ser realizada tanto por uma interpolação Shepard (Método do inverso da distância), ou por uma krigagem. Na Figura 3.2 é mostrado um modelo de baixa frequência construído por meio de krigagem das impedâncias acústicas dos poços [3].

${ }^{2}$ Root Mean Square ou valor eficaz em português: raiz quadrada da média aritmética dos quadrados dos valores 


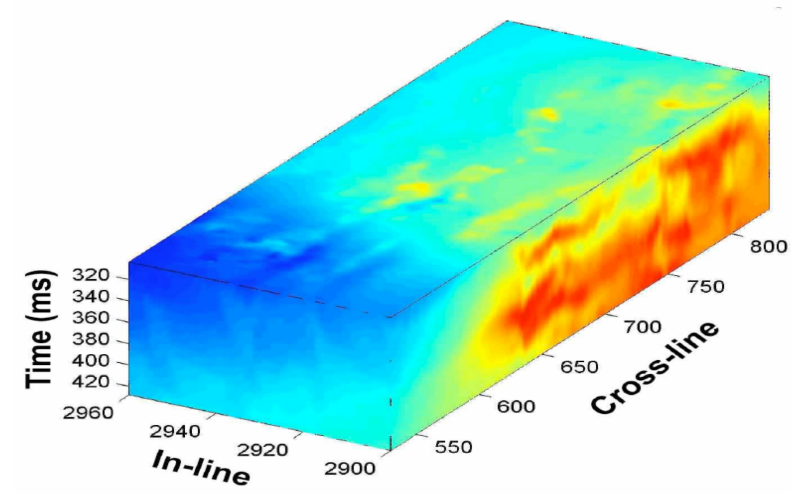

Figura 3.2: Exemplo de um modelo de baixa frequência realizado por krigagem dos dados de impedância acústica nos poços. Figura copiada de Leite, E. P., $2010[3]$

\subsection{7}

\section{Parametrização do algoritmo de inversão}

A inversão sísmica é um processo multi-estágio, onde para cada um desses estágios o geocientista tem uma série de parâmetros para ajustar. Por exemplo, a estimativa da wavelet requer a configuração do tamanho da janela, e a largura de banda para suavização da wavelet. A inversão do volume baseada em Simulated Annealing apresentada na 3.2.8, requer a configuração dos limites de busca do algoritmo, tolerância a convergência, o fator de redução da temperatura e pesos da função objetivo.

A parametrização do algoritmo afeta diretamente a qualidade da inversão, e não é possível a priori definir os melhores parâmetros a serem utilizados. Depende muito da experiência do geocientista, do conhecimento dos modelos matemáticos que dão base para cada um dos estágios. Somente com esses conhecimentos é possível se fazer um bom ajuste desses parâmetros, que na maioria das vezes são interdependentes.

A forma de verificação da qualidade final do algoritmo pode ser alcançada por meio de comparação do resultado final com os dados de poço originais, os quais devem ter uma boa correspondência. O ideal é que esse processo seja feito utilizando técnicas de validação cruzada, no entanto, quando não há dados de poços suficientes, os próprios poços utilizados na inversão podem ser utilizados. A justificativa é que as informações de poços são utilizadas somente no momento da geração do modelo de baixa frequência.

Outro ponto importante é verificar quanto de energia ainda está presente no volume de diferença entre a sísmica original e a sísmica sintética calculada através do modelo convolucional. Espera-se ter apenas uma diferença pequena 
em cada profundidade. Essa análise pode também ser realizada no domínio da frequência, para um melhor ajuste da wavelet.

Como o processo de inversão é muito caro computacionalmente, essa parametrização deve ser realizada em um recortes pequenos do dado, em torno dos poços e preferencialmente apenas em uma seção sísmica. Quando os parâmetros estiverem bem ajustados, aplicamos o algoritmo em todo o volume sísmico.

\subsection{8}

\section{Inversão do volume}

A inversão do volume se refere ao último estágio do projeto de inversão. Nesse momento dados sísmicos e volume de baixa frequência já foram preparados, a wavelet já foi estimada e os parâmetros do algoritmo já estão ajustados. Esse é o processo com menor interação humana, porém dependendo do algoritmo de inversão utilizado pode tornar-se muito caro computacionalmente e levar um tempo muito longo para ser realizado.

A escolha do algoritmo de inversão dita o tempo e a acurácia do resultado, que podem ser por algoritmos baseados em gradientes, onde o número de iterações é relativamente pequeno, ou um método estocástico como Simulated Annealing que explora um espaço de parâmetros muito maior, mas depende de um número de iterações muito superior para alcançar a convergência do modelo [16].

Na Figura 3.3 está representado o algoritmo de inversão, que se inicia a partir do perfil de impedância acústica obtido no modelo de baixa frequência, e limites estabelecidos pelo especialista; à partir desse perfil, calcula-se a refletividade conforme a equação 2-11, utilizando o modelo convolucional descrito pela equação 2-13 e a wavelet extraída conforme descrito na subseção 3.2.4 obtem-se um traço sísmico sintético; O traço sintético é comparado ao traço sísmico real obtido na sísmica e caso a diferença entre os dois seja menor que um limite estabelecido, o algoritmo se encerra e considera a impedância acústica obtida, senão perturba-se o modelo até que esse atinja o erro estabelecido. 


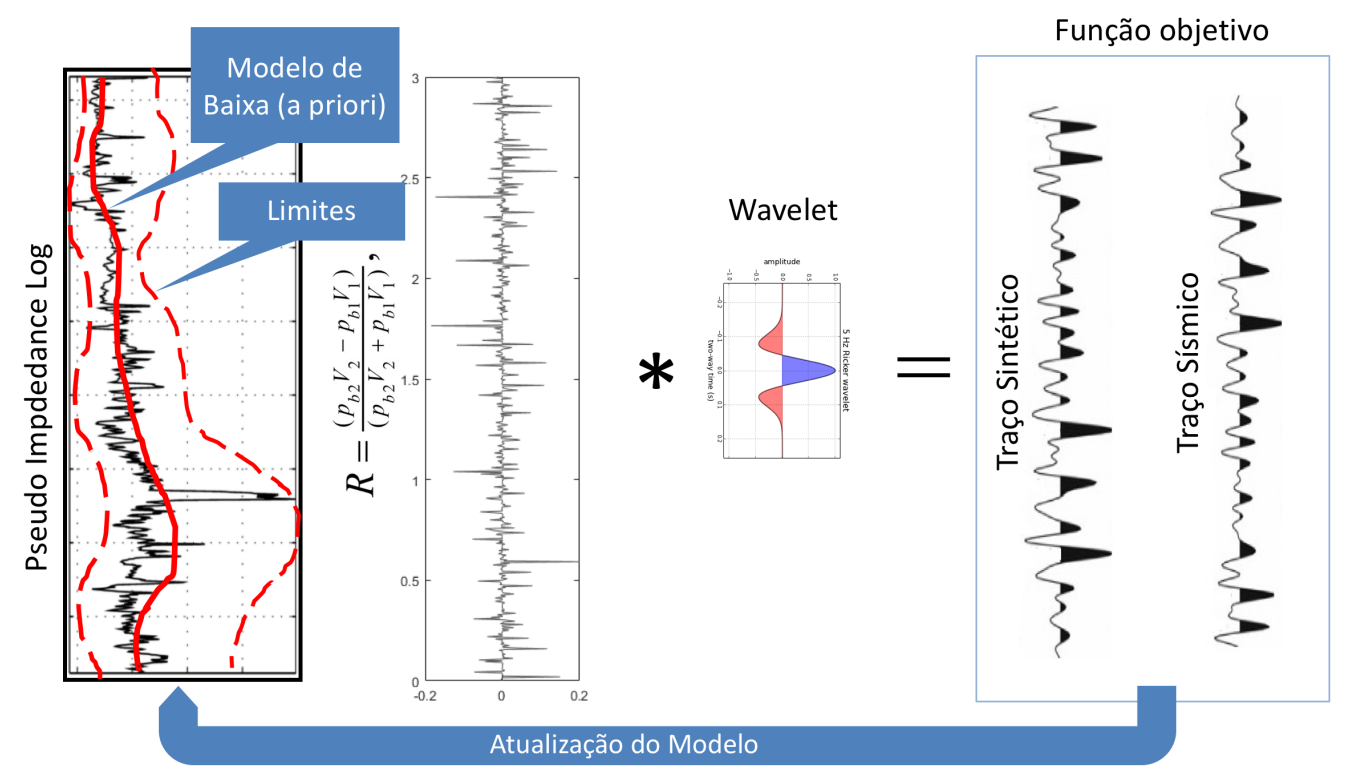

Figura 3.3: Otimização Global da Inversão baseada em Modelos

\section{3}

\section{A Inversão Colorida}

Lancaster e Whitcombe em 2000 [4] publicaram um método rápido para cálculo da Impedância Acústica Relativa conhecido como Inversão Colorida, que parte do princípio que o espectro de amplitude de um perfil de Impedância Acústica no poço é um ruído rosa com caimento exponencial, e que o processo de inversão para impedância relativa pode ser representado por uma operação de convolução.

\subsection{1}

O Algoritmo

Segundo os autores, há apenas dois parâmetros $\alpha$ e $\beta$ constantes e positivos, no qual o perfil de poço em domínio de frequência pode ser representada pela equação:

$$
\alpha f^{\beta}
$$

onde f é a frequência e $\alpha$ e $\beta$ são os parâmetros da curva.

Na Figura 3.4 é apresentado em diferentes cores poços distintos de um mesmo campo, onde pode-se verificar uma tendência comum e linear da impedância acústica em relação à frequência (na escala logarítmica): 


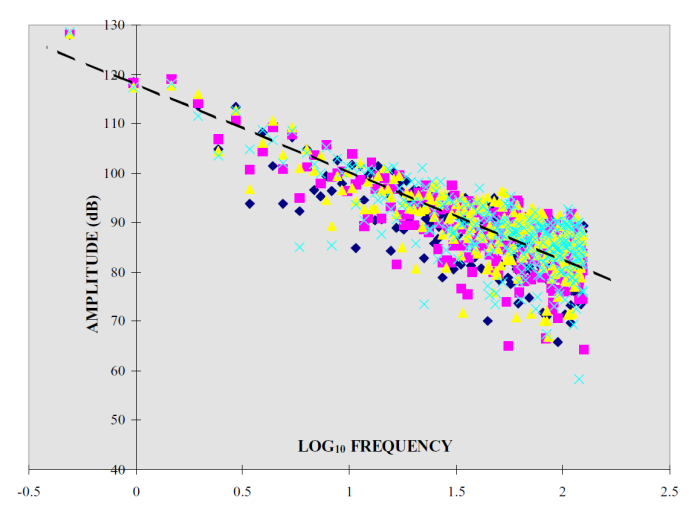

Figura 3.4: Quatro perfis de poços diferentes de um campo do Mar do Norte, representados em logaritmo da frequência, onde podemos claramente ver uma tendência linear, o que equivale a uma exponencial negativa e o coeficiente angular é exatamente o valor de $\beta$. Figura copiada de Lancaster et al. 2000 [4]

Em escala $\log \times \log$, os parâmetros $\alpha$ e $\beta$ representam o coeficiente linear e angular respectivamente, pois se tirarmos o logaritmo da função e utilizando as suas propriedades podemos expandir em:

$$
\log (\alpha)+\beta \log (f)
$$

onde $\beta$ é o coeficiente angular e $\log (\alpha)$ o coeficiente linear.

Como a sísmica é um dado limitado em banda, deve-se limitar o espectro da impedância acústica nos poços, que não são limitados em banda, dentro dos limites do dado sísmico, utilizando um filtro trapezoidal (representado aqui por $t_{a b c d}$ onde $\mathrm{a}<\mathrm{b}<\mathrm{c}<\mathrm{d}$ ) da seguinte forma:

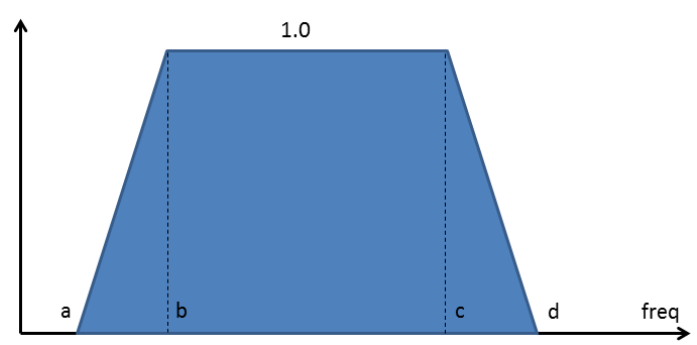

Figura 3.5: Filtro trapezoidal, onde a, b, c e d devem ser ajustados de forma a melhor se adaptar ao conteúdo de frequência da sísmica

Executando-se uma multiplicação ponto a ponto (aqui representada por $\otimes$ ) da curva exponencial média do espectro de amplitude do poço com $t_{a b c d}$, tem-se como saída uma versão limitada em banda da curva:

$$
\hat{p}=\alpha f^{\beta} \otimes t_{a b c d}
$$

O próximo passo é calcular o espectro de amplitude médio da sísmica:

$$
\hat{s}=\frac{\sum_{i=1}^{N} \mid f f t\left(\text { trace }_{i}\right) \mid}{N}
$$


que agora deve ser dividida ponto a ponto (divisão de Hadamard) pelo espectro de amplitude da sísmica, gerando o operador da inversão colorida conforme o exemplo da figura 3.6:

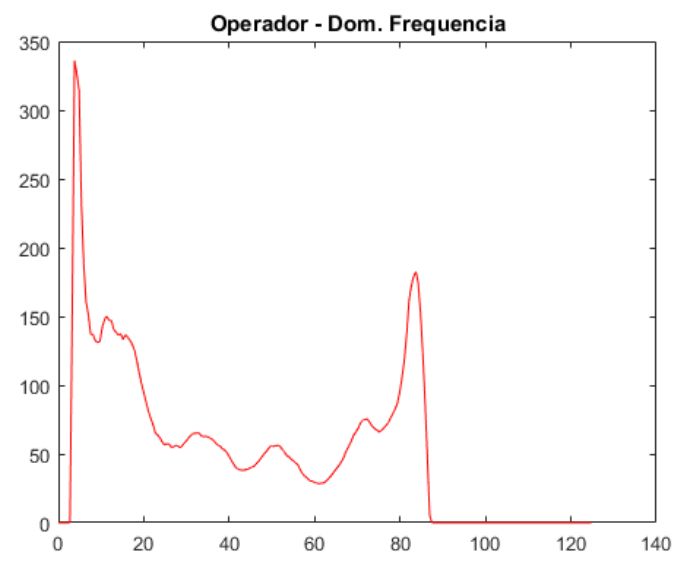

Figura 3.6: Operador no domínio da frequência da inversão colorida

Como o objetivo da inversão sísmica é representar a propriedade de rochas (nesse caso a impedância acústica) e o da sísmica de reflexão representar as interfaces (ou a refletividade), faz-se necessário rotacionar o sinal em $-90^{\circ}$. Para isso, basta efetuar a multiplicação complexa do operador de convolução da inversão colorida por $-i$.

A partir desse ponto, para simplificação dos cálculos, devemos calcular o operador de convolução no domínio de tempo, pois assim pode-se simplesmente convolver o operador traço a traço na sísmica invertendo todo o volume. Para isso utilizamos a transformada inversa de Fourier, obtendo o operador em domínio de tempo dado pela figura 3.7.

O tamanho do operador em domínio de tempo deve ser calculado com o objetivo da manutenção da quantidade total da energia do operador, que no caso do presente trabalho, mantivemos em 99.9\%. Para isso, utiliza-se a identidade de Parseval [18], que diz que a energia é a mesma não importando a representação do operador, em domínio de tempo ou frequência, isto é:

$$
\int_{-\infty}^{\infty}|x(t)|^{2} d t=\frac{1}{2 \pi} \int_{-\infty}^{\infty}|X(j \omega)|^{2} d \omega
$$

Onde $x(t)$ é a função no domínio de tempo e $X(j \omega)$ é a função em domínio da frequência.

ou na sua forma discreta:

$$
\sum_{n=-\infty}^{\infty}|x[n]|^{2}=\frac{1}{2 \pi} \int_{2 \pi}\left|X\left(e^{j \omega}\right)\right|^{2} d \omega
$$

considerando-se somente o lado esquerdo da equação, onde calcula-se a energia no domínio da frequência e calculando-se o valor mínimo de $k$ para que 
a inequação abaixo continue válida, obtemos o tamanho mínimo do operador para a manutenção de $99.9 \%$ da energia.

$$
\frac{\sum_{n=-k}^{k}|x[n]|^{2}}{\sum_{n=-\infty}^{\infty}|x[n]|^{2}} \geqslant 0.99
$$

Ao final do processo, o operador em domínio de tempo da inversão colorida tem a forma mostrada na Figura 3.7.

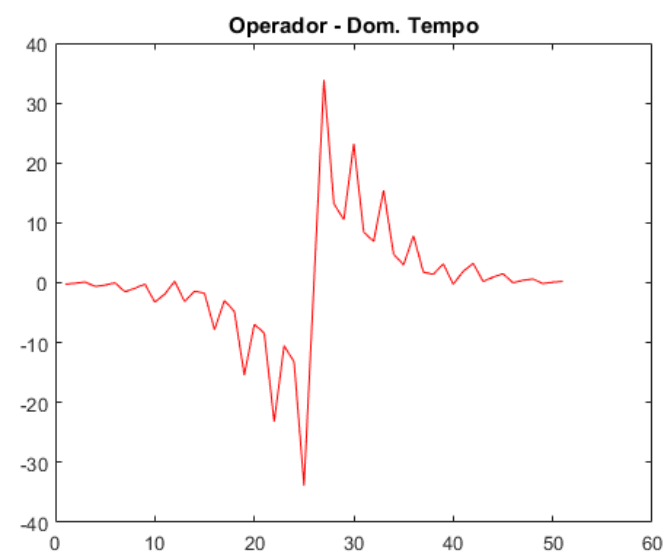

Figura 3.7: Operador no domínio de tempo da inversão colorida

Todo o processo pode ser resumido pela figura $3.8^{3}$ :

(i) Raw Seismic: Nessa etapa calcula-se o espectro de amplitude traço a traço - mostrado em diferentes cores para cada traço individualmente;

(ii) Seismic Mean: A média do espectro de amplitude de todos os traços é calculada (curve vermelha), e tira-se uma tendência suave da curva, através de uma média móvel no espectro de amplitude médio da sísmica;

(iii) Log Input (time domain): utilizando o modelo de velocidade, ou o perfil sônico;

(iv) Log Input Detrended (time domain): Com o objetivo de melhorar a estabilidade do cálculo da transformada de Fourier, retira-se a tendência linear do perfil em domínio de tempo;

(v) Individual Wells: Calcula-se a transformada de Fourier de poço a poço, em escala $\log \times \log$;

(vi) Global: A partir da transformada de Fourier de cada poço, tira-se a média global e a linha de tendência, para o cálculo de $\alpha$ e $\beta$ a partir dos coeficientes linear e angular na equação 3-8;

${ }^{3}$ ARK CLS Seismic Coloured Inversion V4.1 Software Manual - http://www.arkcls . com/wp-content/docs/SCI/gf/latest/: Acesso em 12 de fevereiro de 2018 
(vii) Design Operator: Divisão ponto a ponto entre o espectro do poço e média da sísmica para encontrar o operador em domínio de frequência;

(viii) Operator (time domain): Aplicação da Transformada de Fourier Inversa sobre o operador em domínio de frequência para encontrar o operador em domínio de tempo;

(ix) Residual Operator (QC): Diferença entre o operador ideal e o realizável;

(x) Convolved Output Mean (QC): Média do espectro do resultado na saída da inversão colorida.
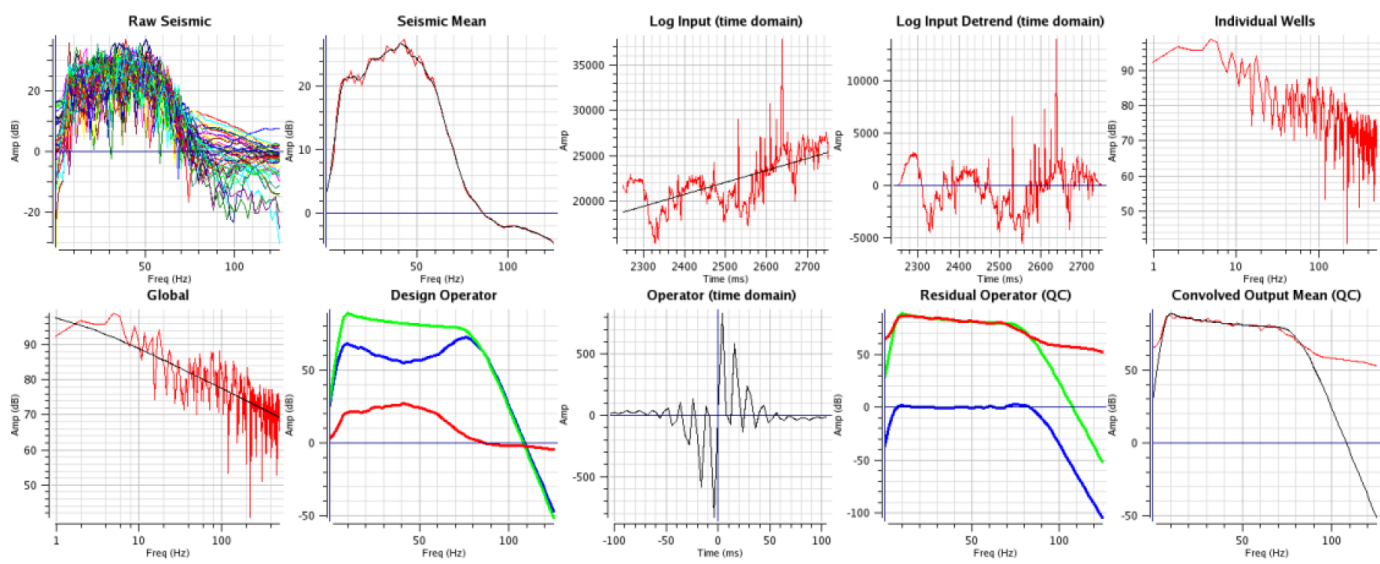

Figura 3.8: Resumo do fluxo completo da inversão Colorida - Figura copiada do Manual do software ARK CLS Seismic Coloured Inversion V4.1 


\section{4}

\section{Trabalhos Relacionados}

O trabalho de Kuroda et al [5] apresenta uma metodologia baseada em Algoritmos Genéticos e Redes Neurais Artificiais para estimar a porosidade em um volume sísmico, utilizando diversos atributos sísmicos.

A partir de um conjunto de atributos listado na tabela 4.1, o objetivo de seu trabalho foi executar o algoritmo genético mostrado no fluxograma da 4.1, com a seguinte função objetivo:

$$
P_{m}=\frac{1}{n} \sum_{i=1}^{n}\left(\hat{Y}_{i}-Y_{i}\right)^{2} \times\left(\frac{A_{c}}{A_{p}}\right)
$$

onde:

$A_{c}$ é o número de atributos selecionados para o indivíduo;

$A_{p}$ é o número de atributos existentes (37 nesse caso específico);

$\hat{Y}_{i}$ é o i-ésimo vetor de valores preditos;

$Y_{i}$ é o i-ésimo vetor de valores reais;

o somatório é o erro médio quadrático (MSE) sobre todas as amostras. 


\begin{tabular}{|c|c|}
\hline Número & Nome do atributo sísmico \\
\hline 1 & $3 \mathrm{D} \operatorname{mix}$ \\
\hline 2 & Amplitude envelope \\
\hline 3 & Automatic gain control \\
\hline 4 & Band-pass filter $(6-60 \mathrm{~Hz})$ \\
\hline 5 & Colored inversion \\
\hline 6 & Spectral Decomposition $10 \mathrm{~Hz}$ Euc \\
\hline 7 & Spectral Decomposition $20 \mathrm{~Hz}$ Euc \\
\hline 8 & Spectral Decomposition 30Hz Euc \\
\hline 9 & Spectral Decomposition $40 \mathrm{~Hz}$ Euc \\
\hline 10 & Spectral Decomposition $50 \mathrm{~Hz}$ Euc \\
\hline 11 & Spectral Decomposition $60 \mathrm{~Hz}$ Euc \\
\hline 12 & Spectral Decomposition $70 \mathrm{~Hz}$ Euc \\
\hline 13 & Spectral Decomposition 80Hz Euc \\
\hline 14 & Envelope balancing \\
\hline 15 & Exponential gain \\
\hline 16 & Fault moment filter \\
\hline 17 & FX deconvolution $(6-60 \mathrm{~Hz})$ \\
\hline 18 & FXY deconvolution $(6-60 \mathrm{~Hz})$ \\
\hline 19 & Gaussian XY smoother \\
\hline 20 & Acoustic impedance \\
\hline 21 & Incoherence \\
\hline 22 & Instantaneous phase \\
\hline 23 & Instantaneous frequency \\
\hline 24 & Loop deconvolution \\
\hline 25 & Peak spectral frequency \\
\hline 26 & $90^{\circ}$ phase rotation \\
\hline 27 & Recursive inversion \\
\hline 28 & Scalar math (exponentiate 5) \\
\hline 29 & Structure oriented median filter \\
\hline 30 & Sparse spike deconvolution \\
\hline 31 & Sparse spike deconvolution 3D \\
\hline 32 & Sweetness \\
\hline 33 & Time variant zero phase deconvolution \\
\hline 34 & Trace equalization \\
\hline 35 & Trapezoid filter \\
\hline 36 & Velocity cube \\
\hline 37 & Zero phase deconvolution \\
\hline
\end{tabular}

Tabela 4.1: Conjunto de atributos sísmicos na escala de perfil usados no otimizador GA. O algoritmo para obtenção de cada um dos atributos sísmicos e sua interpretação pode ser encontrada em [9] 


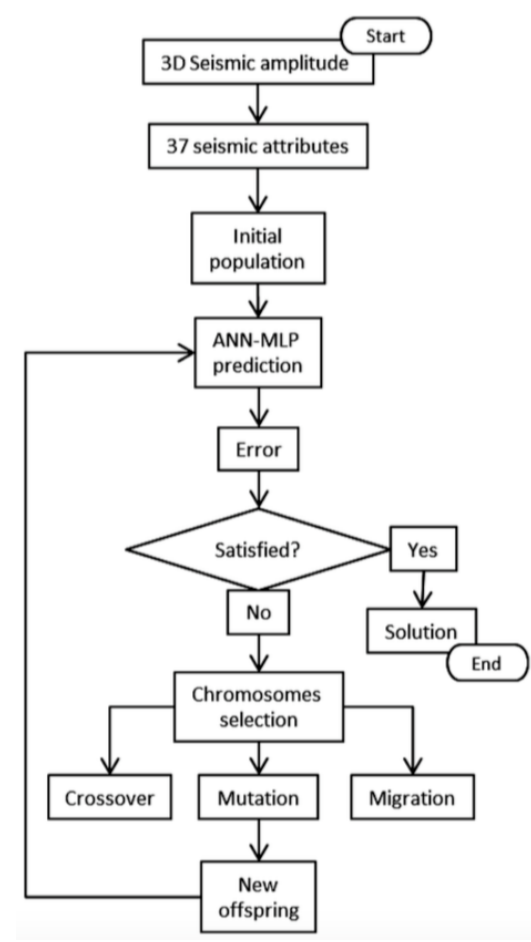

Figura 4.1: Fluxograma do algoritmo proposto por Kuroda et al. contendo a rede neural para estimativa da porosidade e o algoritmo genético que objetiva encontrar o melhor conjunto de atributos. Figura copiada de Kuroda et al, 2016 [5]

As tabelas 4.2 e 4.3 apresentam os parâmetros no algoritmo genético e na rede neural respectivamente utilizados no fluxograma da Figura 4.1.

Parâmetro do Algoritmo Genético

\begin{tabular}{ll}
\hline Fitness function & MLP \\
Fitness limit & $5 \times 10^{5}$ \\
Population type & Binary \\
Number active genes & $2-37$ \\
Size of population & 50 \\
Number of generations & 200 \\
Select type & Tournament \\
Crossover function & Scattered \\
Number of migrated genes & 10 \\
\hline
\end{tabular}

Tabela 4.2: Parâmetros usados no algoritmo de seleção de atributos baseado em GA 


\begin{tabular}{ll} 
Hiper-Parâmetros da Rede Neural & \\
\hline Activation function & Sigmoid \\
Fitness limit & $5 \times 10^{5}$ \\
Neurons in hidden layer & 3 \\
Train algorithm & Levenberg-Marquardt Backp \\
Epochs number & 300 \\
Momentum ratio & 0.9 \\
Increment ratio of learning & 0.05 \\
Decrement ratio of learning & 0.01 \\
Max error increment & 0.04 \\
Validation & Cross validation \\
Error function & MSE \\
\hline
\end{tabular}

Tabela 4.3: Parâmetros usados no algoritmo de Redes Neurais para estimativa da porosidade

Ao final da execução obteve-se um resultado de MSE de 0.00396 e R2 Score médio de 0.84, como mostrado na figura 4.2, o que é um resultado muito bom, frente às incertezas na indústria de Óleo e Gás. Os atributos da tabela 4.1 selecionados de forma automática pelo algoritmo genético são os seguintes:

1. Impedância Acústica;

2. Structure-oriented median-filtered amplitude (median SOF);

3. 3D mix. 

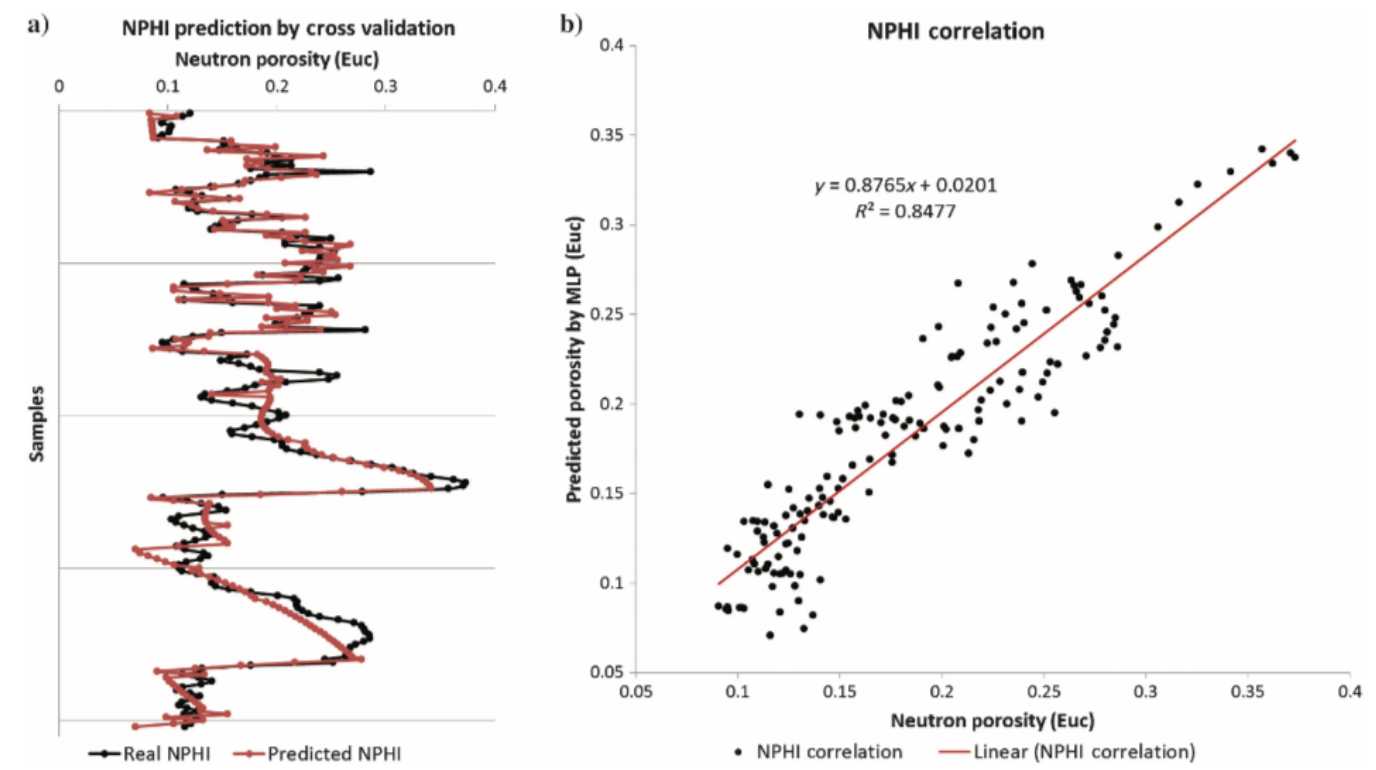

Figura 4.2: Resultados da estimativa de porosidade (em vermelho) quando comparadas aos dados reais em poços (em preto). Figura copiada de Kuroda et al, 2016 [5]

Um ponto importante a ser comentado no trabalho de Kuroda [5] é a presença de diversos atributos, que ao final reduziram-se apenas ao de impedância acústica e dois filtros estruturais da amplitude sísmica, o que mostra que na verdade a rede neural consegue combinar as amostras do traço de maneira mais eficiente para uma predição de propriedade do que uma engenharia de atributos.

De Groot [6] em seu trabalho, utilizou uma abordagem um pouco diferente, porém não menos poderosa, com o mesmo objetivo do trabalho de Kuroda et al apresentado anteriormente, o cálculo da porosidade. Como mostrado na figura 4.3, ele implementou uma janela deslizante sobre os traços sísmicos, que funcionam de forma semelhante a uma rede neural convolucional e assim de certa forma evitando a necessidade de utilização de diversos atributos sísmicos de amplitude, pois a própria rede intrinsecamente se encarrega de combinar as amplitudes da vizinhança fazendo o melhor "atributo"a ser utilizado naquele cálculo. 


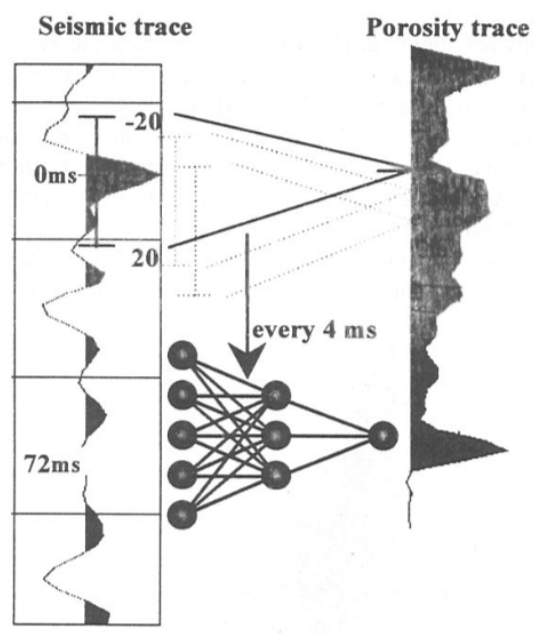

Figura 4.3: Modelagem da Rede Neural de uma camada escondida proposta por De Groot, utilizando uma janela deslizante sobre as amostras do traço sísmico. Figura copiada de De Groot, 1999 [6]

Adicionalmente às amostras de amplitude sísmica, ele utilizou a impedância acústica e o tempo de trânsito da onda, como mostrado na figura 4.4. Assim como no caso do trabalho anterior, o objetivo da utilização da impedância acústica é que esta pode ser facilmente correlacionada com outras propriedades petrofísicas, entre elas a própria porosidade. O tempo de trânsito por outro lado representa a variação de resolução, velocidade e comprimento de onda apresentados em 2.1.4.

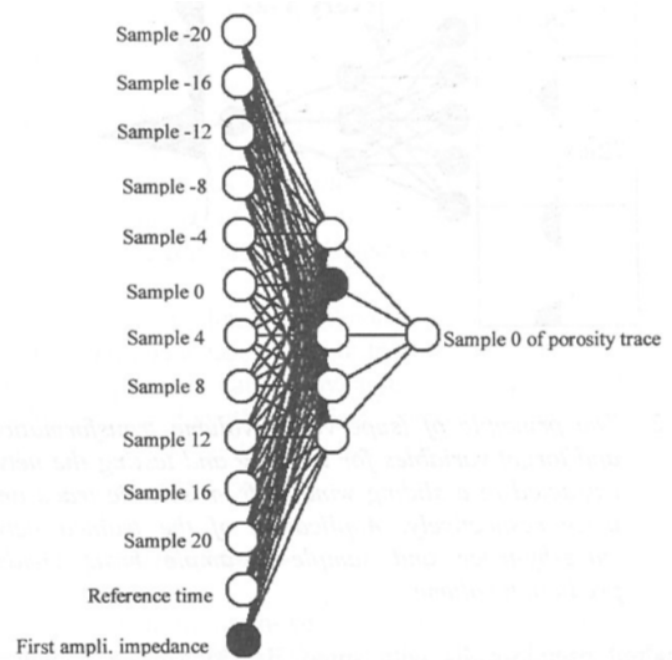

Figura 4.4: Definição de cada atributo nos neurônios de entrada com a janela deslizante, o tempo de trânsito da onda e a impedância acústica. Figura copiada de De Groot, 1999 [6]

Apesar de De Groot em seu trabalho não apresentar resultados quantitativos em termos de R2, como foi feito no trabalho de Kuroda et al, ele apresenta 
resultados qualitativos em forma de gráficos na Figura 4.5, apresentando a boa correlação entre os dados de porosidade real (nos poços) e a predita utilizando a rede neural.
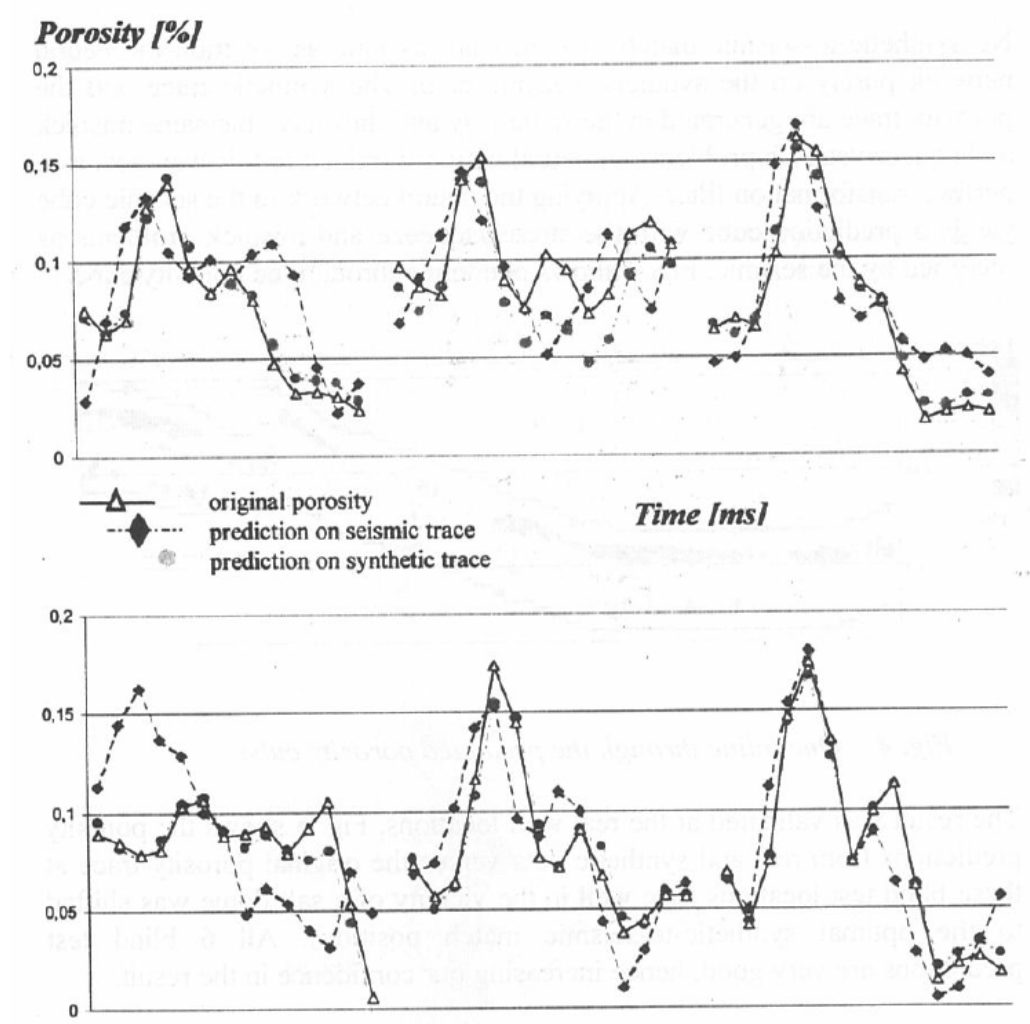

Figura 4.5: Comparativo da predição da porosidade e do valor real realizado por De Groot. Figura copiada de De Groot, 1999 [6]

Como pode-se observar De Groot utiliza apenas a impedância acústica e uma janela móvel nos traços de impedância e nenhum outro atributo sísmico. Isso nos leva a crer que a rede neural seja capaz de estimar a melhor combinação das amplitudes ao longo do traço, sem a necessidade de nenhuma engenharia de atributos sobre os traços sísmicos.

Outro artigo de Chopra e Misra [7] mostra resultados bastante promissores de uma inversão sísmica para impedância acústica baseada em Redes Neurais Probabilísticas, no entanto o artigo não apresenta os atributos utilizados, tampouco a topologia da rede.

O valor desse artigo para a presente dissertação é que demonstra a viabilidade da técnica. O resultado pode ser visto comparando-se a Figura 4.6 onde é mostrado o resultado da impedância acústica estimada através de uma inversão baseada em Modelos e a Figura 4.7, onde a mesma estimativa é realizada por meio de uma rede neural probabilística. O artigo mostra inclusive comparando os dois resultados que a rede neural foi capaz de resolver estruturas mais delgadas, como mostrado na área circulada. 


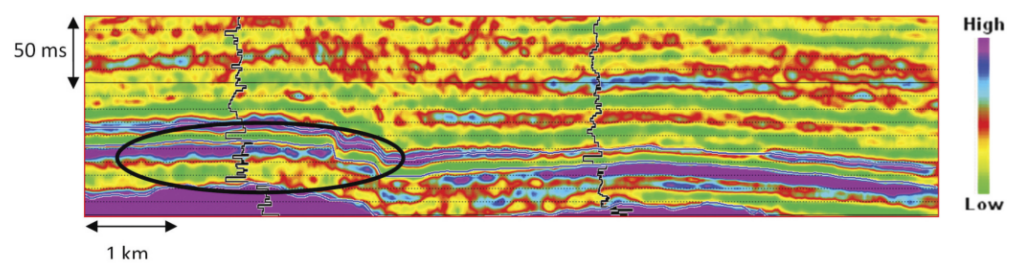

Figura 4.6: Resultado obtido da estimativa de impedância acústica utilizando uma inversão baseada em modelos. Figura copiada de Misra et al, 2011 [7]

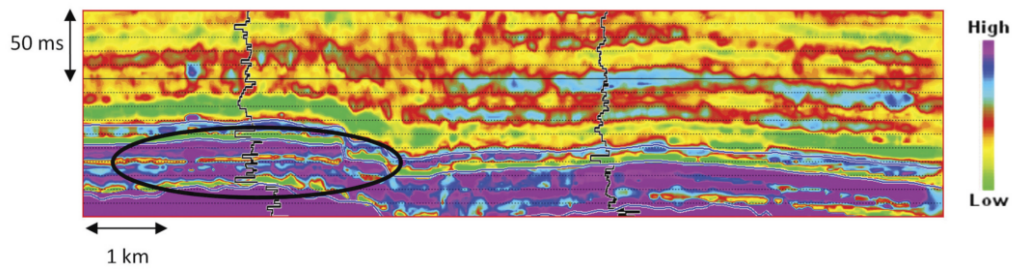

Figura 4.7: Resultado obtido da estimativa da impedância acústica utilizando uma Rede Neural Probabilística. Figura copiada de Misra et al, 2011 [7] 


\section{Inversão acústica baseada em Redes Neurais Artificiais}

Este capítulo estuda a utilização de Redes Neurais Artificiais para o cálculo da Impedância Acústica em volumes sísmicos 3D, revisitando os métodos de inversão baseados em modelos.

Segundo Hampson [19], qualquer perfil de poço pode ser estimado a partir de um conjunto de atributos sísmicos. Baseado nessa premissa, o primeiro objetivo é encontrar qual o conjunto de atributos sísmicos que deve ser utilizado como base para uma melhor regressão de Impedância Acústica, e a partir disso, o melhor conjunto de hiper-parâmetros para a rede neural.

Outro objetivo da técnica proposta é abreviar o fluxo de trabalho a ser realizado pelo geofísico, como descrito por Ma em [17] e também apresentado na seção 3.2. No fluxo mostrado na Figura 5.1, podemos observar que que foram retiradas as caixas em cinza da Figura ??. No fluxo proposto as caixas Seleção de um traço sísmico próximo ao poço e Análise de Amarração de Poços estão circuladas por uma caixa chamada Cálculo do Modelo de Velocidade, que normalmente é disponível como um dado externo. Note também que nesta dissertação o passo Inversão do Volume é dividido em treinamento e aplicação da rede neural.

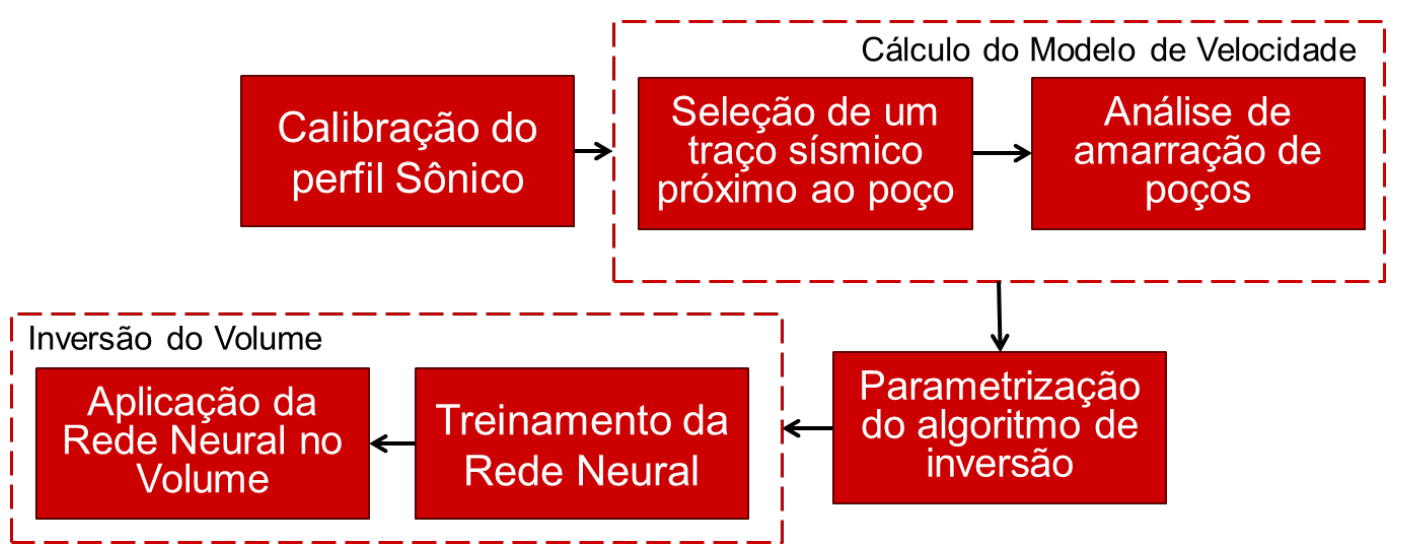

Figura 5.1: Fluxo de uma inversão sísmica utilizando redes neurais artificiais proposto nesta dissertação

No texto que segue, nosso método é apresentado em conjunto com um exemplo. Espera-se que isso facilita o entendimento dos passos do processo, 
uma vez que o leitor pode verificar o avanço nos resultados com a inclusão de um novo atributo ou uma mudança na topologia.

\section{1}

\section{O Dataset}

O dataset utilizado foi o do bloco offshore F3 do mar do Norte (na localização ilustrada na Figura $5.2^{1}$ ), que é um dado público para fins educacionais ou de pesquisa e é disponibilizado no formato OpenDTect ${ }^{2}$ ou SEG-Y/LAS ${ }^{3}$.

$\mathrm{O}$ critério para a escolha do dataset foi atender às seguintes especificações abaixo:

(i) Ser um dado público;

(ii) Disponibilidade de Volume sísmico 3D;

(iii) Disponibilidade de Modelo de velocidade;

(iv) Disponibilidade de dados de poço com velocidade e densidade;

(v) Disponibilidade de volume de impedância (invertido) para comparação dos resultados;

(vi) Disponibilidade de horizontes topo e base na região de interesse;

(vii) Ser um dado com tamanho suficiente para treinar a rede em uma porção do volume e executar em outra.

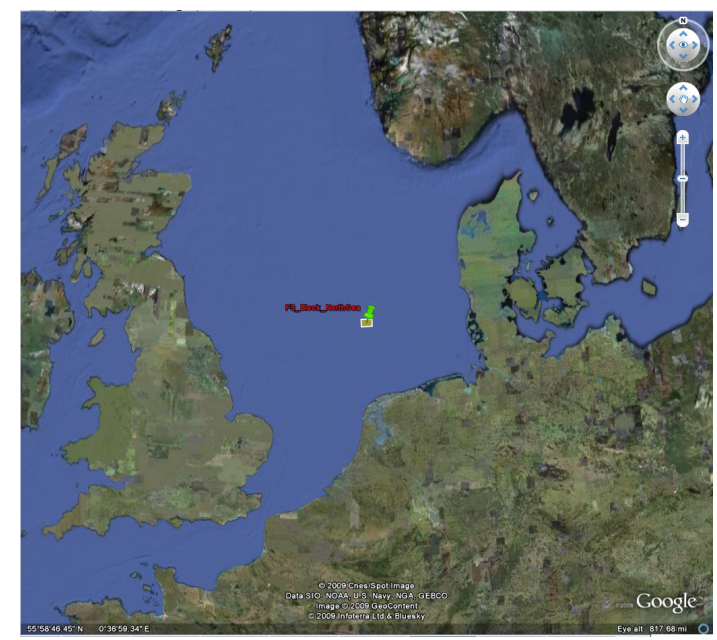

Figura 5.2: Localização no Mapa do Campo F3 no Mar do Norte

${ }^{1}$ Imagem extraida do Open Seismic Repository do OpendTect: https : //www . opendtect . org/osr/Main/NetherlandsOffshoreF3BlockComplete4GB - Acesso em 27 de fevereiro de 2018

${ }^{2}$ Software Livre de interpretação Sísmica - http://opendtect.org

${ }^{3}$ http://opendtect.org/osr/pmwiki.php/Main/NetherlandsOffshoreF3BlockComplete4GB 
A tabela 5.1 mostra os parâmeros de aquisição do dado F3. A linha Inline range nesta tabela indica que na direção de aquisição temos 650 seções numeradas de 100 a 750 com passo de 1. A linha Crossline range indica que temos 950 seções na direção ortogonal ao levantamento numeradas de 300 a 1250 com passo de 1. A distancia entre as seções é fornecida na linha Bin range, nesse caso 25 metros tanto para inline quanto para crossline. A linha $Z$ Range é o Record Length de cada traço: 462 amostras espaçadas de 4 mili-segundos. O tamanho da área da aquisição sísmica é dado na última linha,Size (km).

\begin{tabular}{llll}
\multicolumn{4}{c}{ Sísmica do F3 } \\
\hline Inline range & 100 & 750 & step 1 \\
Crossline range & 300 & 1250 & step 1 \\
Bin size $(\mathrm{m})[\mathrm{inl} / \mathrm{xl}]$ & 25 & 25 & \\
Z range $(\mathrm{ms})$ & 0 & 1848 & step 4 \\
Size $(\mathrm{km})$ & $24 \times 16$ &
\end{tabular}

Tabela 5.1: Parâmetros de aquisição sísmica do dataset F3

A Figura $5.3^{4}$ mostra uma tela do software OpendTect com dados do F3 com os poços desenhados como linhas verticais. Como pode-se observar, essa área tem somente quatro poços mal distribuídos. Três poços estão, inclusive, próximos à fronteira, dificultando uma inversão com base neles.

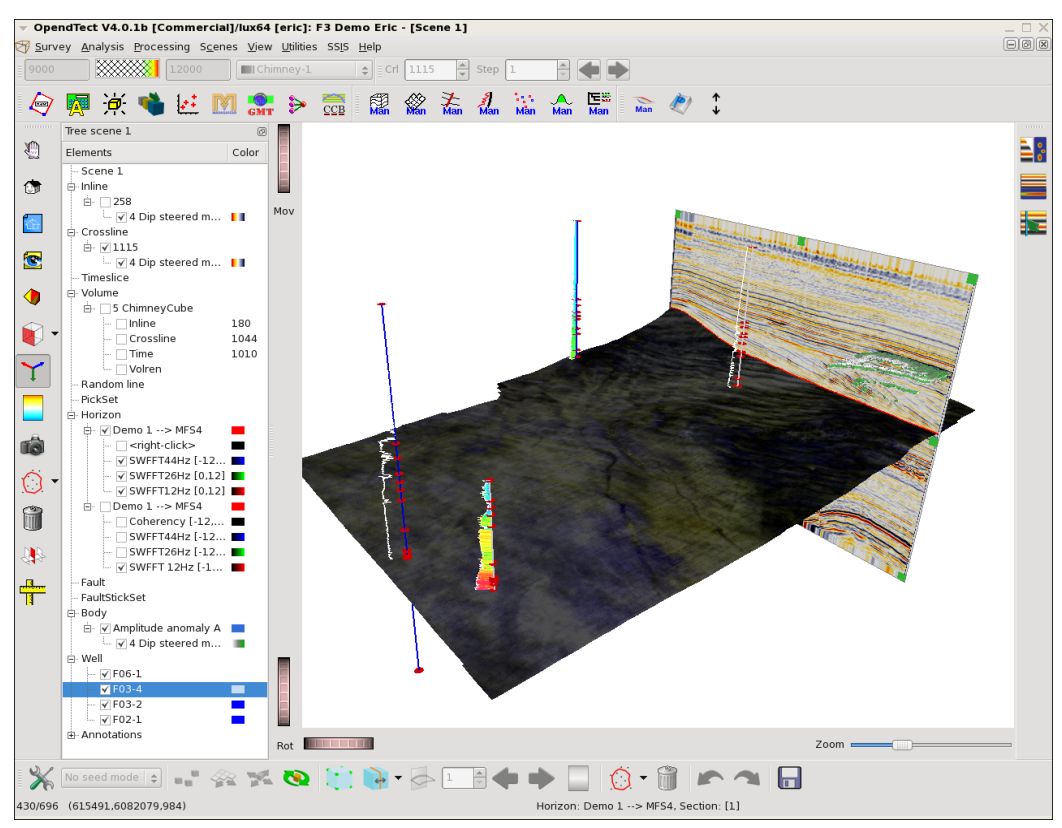

Figura 5.3: Localização dos poços no no Campo F3

\footnotetext{
${ }^{4}$ Imagem extraida do Open Seismic Repository do OpendTect: https : / www . opendtect . org/osr/Main/NetherlandsOffshoreF3BlockComplete4GB - Acesso em 27 de fevereiro de 2018
} 
Na tabela 5.2 são mostrados os perfis de cada um dos poços presentes no Dado F3, onde:

- Caliper: é o perfil que mede o diâmetro do poço;

- Density: é o perfil que mede a densidade da formação;

- Gamma Ray, GR: é o perfil que mede a radioatividade natural das formações;

- P-Wave: é o perfil que mede a velocidade da onda compressional;

- Porosity: é o perfil que mede a porosidade da matriz da rocha;

Uma melhor descrição desses perfis pode ser encontrado em [20].

\begin{tabular}{ll}
\hline \multicolumn{3}{l}{ Dados de Poços disponíveis em F3 } \\
Poço & Perfis \\
\hline F02-1 & Caliper, Density, GR, P-Wave, Porosity \\
F03-2 & Density, GR, P-Wave, Porosity \\
F03-4 & Density, GR, P-Wave, Porosity \\
F06-1 & Density, GR, P-Wave, Porosity \\
\hline
\end{tabular}

Tabela 5.2: Poços disponíveis no Dado F3 com seus perfis disponíveis

Como a inversão apresentada nesse trabalho tem o objetivo de estimar apenas a impedância acústica, os perfis de interesse são apenas o $P$-Wave e o Density.

\subsection{1}

\section{Estratégia de treinamento e validação}

Como os poços deste dataset estão mal distribuídos e não temos garantia da amarração com o dado sísmico, optamos por utilizar o dado de impedância acústica já disponível como dados de treinamento e teste, porém em duas inlines diferentes. Utilizamos a inline 425 como dados de treinamento e a inline 362 para validação. Estas inlines estão ilustradas na figura 5.4. A escolha dessas duas inlines foi devido ao fato delas conterem dois poços. 

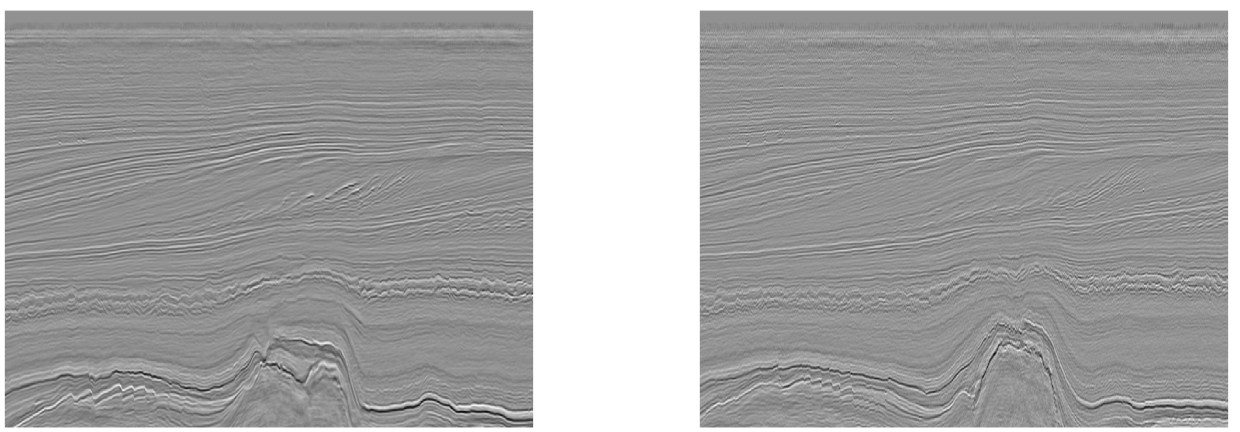

Figura 5.4: Inlines 425 e 362 do dado de F3, utilizadas para treinamento e validação, respectivamente

\section{2}

\section{Reprodução do algoritmo de Inversão Sísmica Colorida utilizando Redes Neurais Artificiais}

Como primeiro passo para testar a hipótese de que podemos representar uma inversão sísmica a partir de uma rede neural, a Inversão Colorida parece uma escolha mais lógica, uma vez que é uma operação linear e que pode ser representada por uma convolução.

A Figura 5.6 apresenta a topologia proposta para a reprodução da inversão colorida utilizando a mesma estratégia de De Groot [6]. Nesta estratégica as entradas são as amostras do traço sísmico em uma janela deslizante. A rede tem apenas uma camada, uma função de ativação linear e um único valor na saída. Essa topologia pode ser interpretada exatamente como uma operação de convolução onde os pesos sinápticos entre a camada de entrada e a de saída representam o valores do núcleo da convolução. Espera-se então que seja possível representar com precisão o comportamento da inversão colorida através dessa rede neural.

Para isso, foi necessário implementar nesta dissertação o algoritmo descrito em 3.3 não somente para comparar os resultados, mas também para a definição do número de neurônios na camada de entrada utilizando a inequação 3-13. Os resultados podem ser vistos na figura 5.5. 

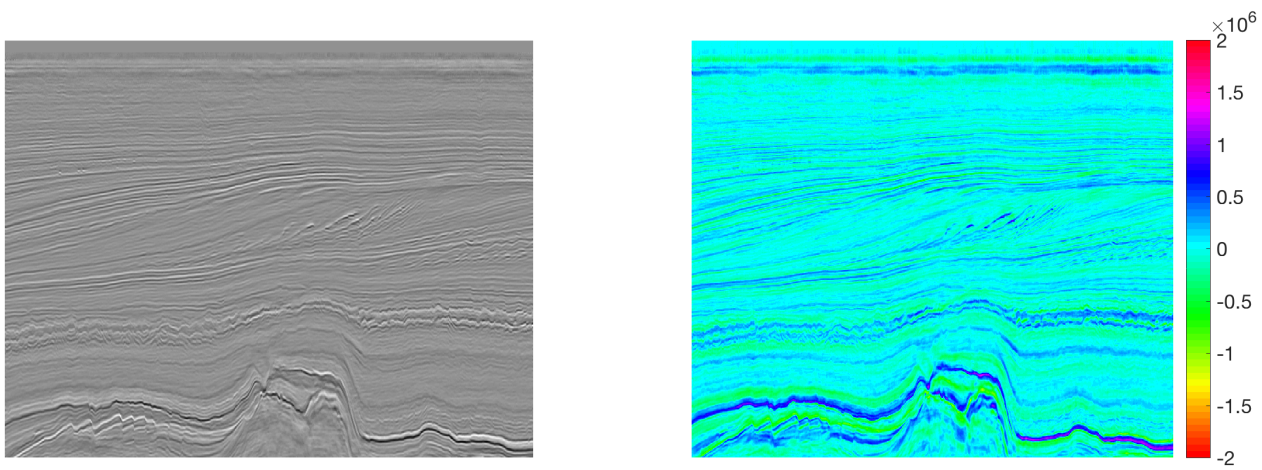

Figura 5.5: Inline 425 de F3: à esquerda se encontra a sísmica original, e à direita o resultado da Inversão Colorida. A escala mostra a impedância Acústica Relativa em $\mathrm{Pa} \cdot s / \mathrm{m}^{3}$

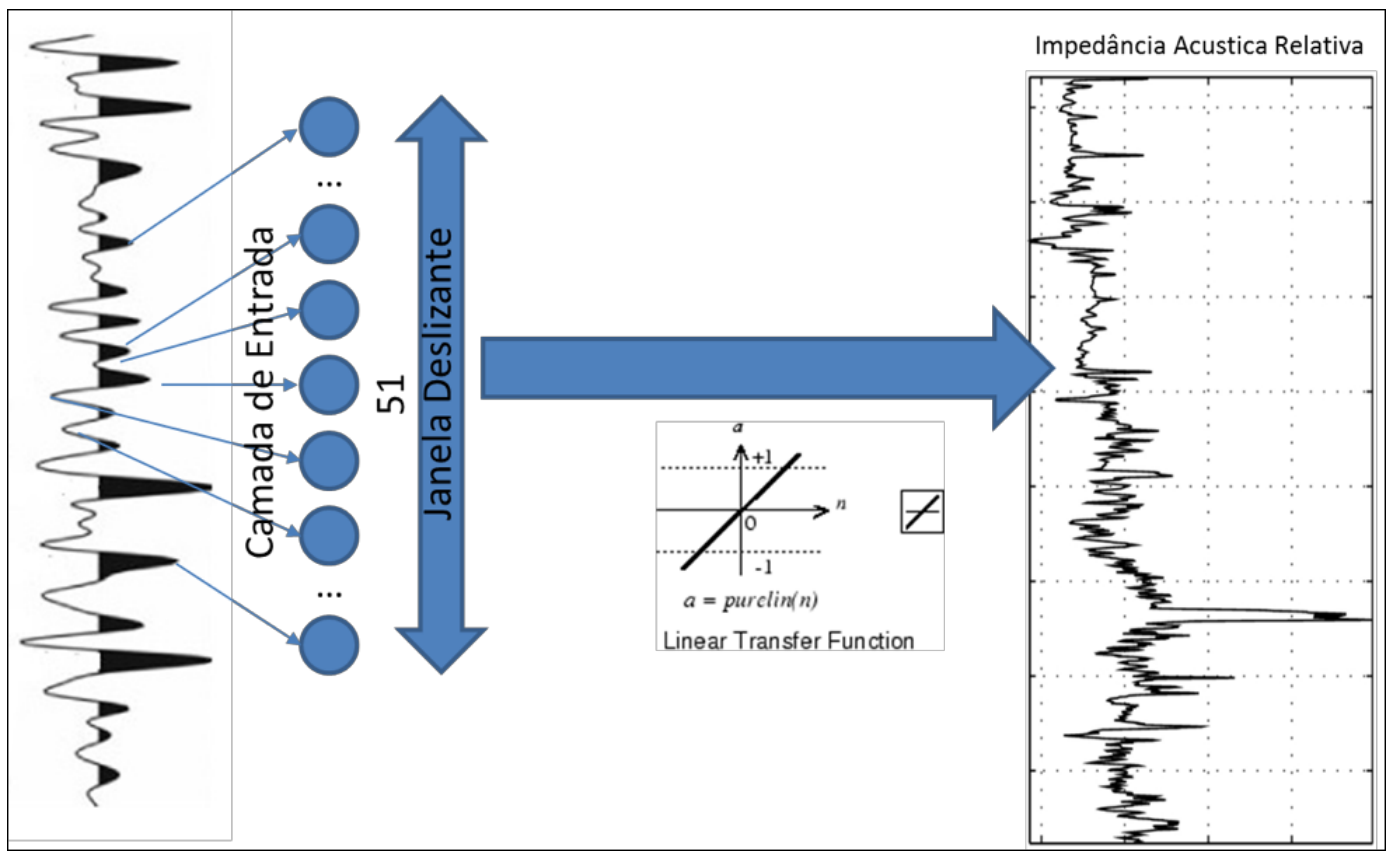

Figura 5.6: Topologia da rede neural artificial utilizada na inversão colorida

A tabela 5.3 abaixo mostra todos os hiper-parâmetros escolhidos para a implementação da Rede Neural: 


\begin{tabular}{ll}
\hline \multicolumn{2}{c}{ Hiper-Parâmetros da Rede Neural } \\
\hline Função de ativação & Linear \\
Número de camadas escondidas & 0 \\
Neurônios na camada de entrada & 51 \\
Medida de Performance & Erro Médio Quadrático (MSE) \\
Número máximo de épocas & 1000 \\
Estratégia de regularização & Early stopping \\
Função de treinamento & Scaled Conjugate Gradient \\
Validação & Randômica - Treinamento: 70\%, \\
& Teste: 15\%, Validação: 15\% \\
\hline
\end{tabular}

Tabela 5.3: Hiper Parâmetros da Rede Neural utilizada para representar uma Inversão Sísmica Colorida

Utilizando o resultado mostrado na Figura 5.5, isto é, o dado de amplitude na inline 425 e o resultado da inversão colorida da mesma inline para treinamento, chegando-se ao modelo treinado da Figura 5.6. Aplicando-se então a rede treinada na inline 362 (conjunto de teste) e comparando aos resultados obtidos a partir da inversão colorida, podemos verificar qualitativamente na Figura 5.7 que os resultados são idênticos, a menos das bordas, que por se tratar de uma janela deslizante o resultado só pode ser calculado na porção onde a janela estaria completa. Quantitativamente pode ser comparado na figura 5.8 , onde verifica-se que em todos os traços o $R 2$ Score é exatamente 1.0, o que significa que a reprodução do algoritmo utilizando a rede neural foi fiel.
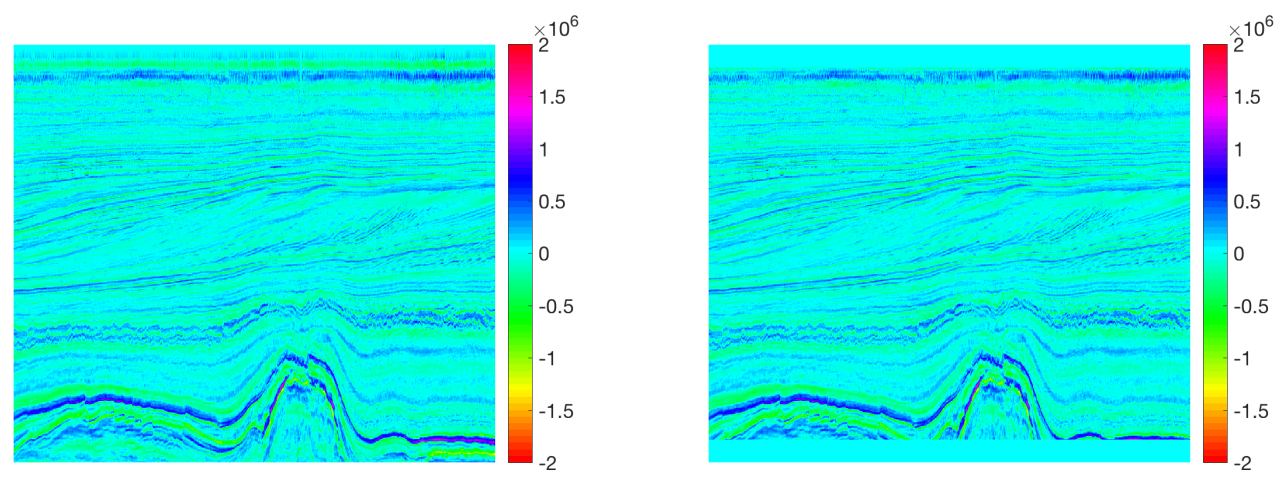

Figura 5.7: Inline 362 de F3 utilizado para validação do algoritmo, onde a primeira imagem é Inversão Sísmica realizada a partir do algoritmo de Inversão Colorida, e a segunda utilizando a Rede Neural 


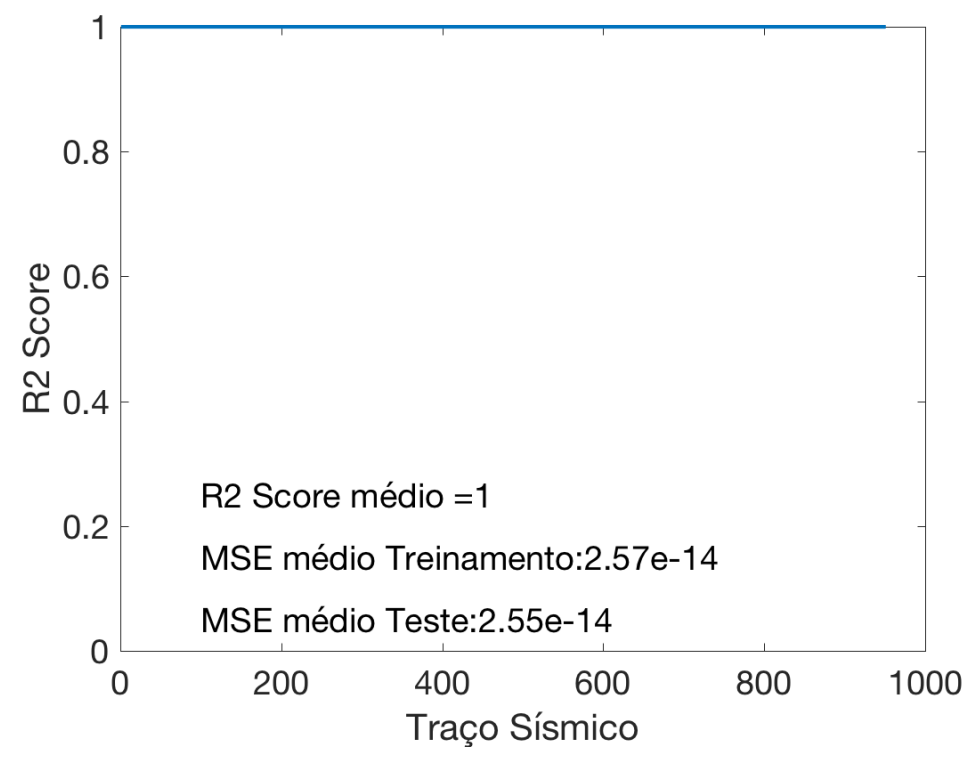

Figura 5.8: R2 Score (em azul) calculado traço a traço entre o resultado obtido pelo método tradicional e pelo método proposto na inline 362

Esse resultado mostrou que a técnica era promissora, o que levava a crer que poderíamos modelar o problema com uma rede neural mais complexa, isto é com um número de camadas superior, assim como funções de ativação não-lineares que pudessem reproduzir o algoritmo de Inversão Baseada em Modelos.

\section{3}

\section{Reprodução do algoritmo de Inversão Sísmica baseada em Modelos utilizando Redes Neurais Artificiais}

A partir dos resultados positivos da reprodução da Inversão Colorida, como apresentado em 5.2 o próximo passo é conseguir representar por meio de uma rede neural uma Inversão Baseada em Modelos, algoritmo introduzido em 3.2.

O desenvolvimento da solução nesse caso foi dividida em dois passos, que são discutidos respectivamente nas subseções 5.3 .1 e 5.3.2:

(i) Modelar a melhor topologia da rede neural: partindo do princípio que a Inversão Baseada em Modelos é um algoritmo não-linear, uma topologia mais complexa da Rede Neural é necessária.

(ii) Encontrar um conjunto de atributos sísmicos: como a sísmica de reflexão é um dado limitado em banda, para que seja possível o cálculo da Impedância Acústica Absoluta, outras fontes de informação além do dado sísmico são necessários. 
A figura 5.9 apresenta a modelagem final da rede neural com os atributos que tiveram o melhor desempenho na estimativa da impedância acústica para a reprodução de um algoritmo de Inversão baseado em Modelos, onde à esquerda é um traço sísmico de amplitude, à direita um perfil de impedância acústica, utilizados como entrada e saída para treinamento da rede neural. Representadas no centro a camada de entrada de 51 neurônios, uma camada escondida de 9 neurônios com função de ativação sigmoidal, e um neurônio na saída reproduzindo a impedância acústica. Nas seções subsequentes do trabalho são apresentadas as decisões tomadas para chegar a esse modelo, assim como os atributos utilizados.

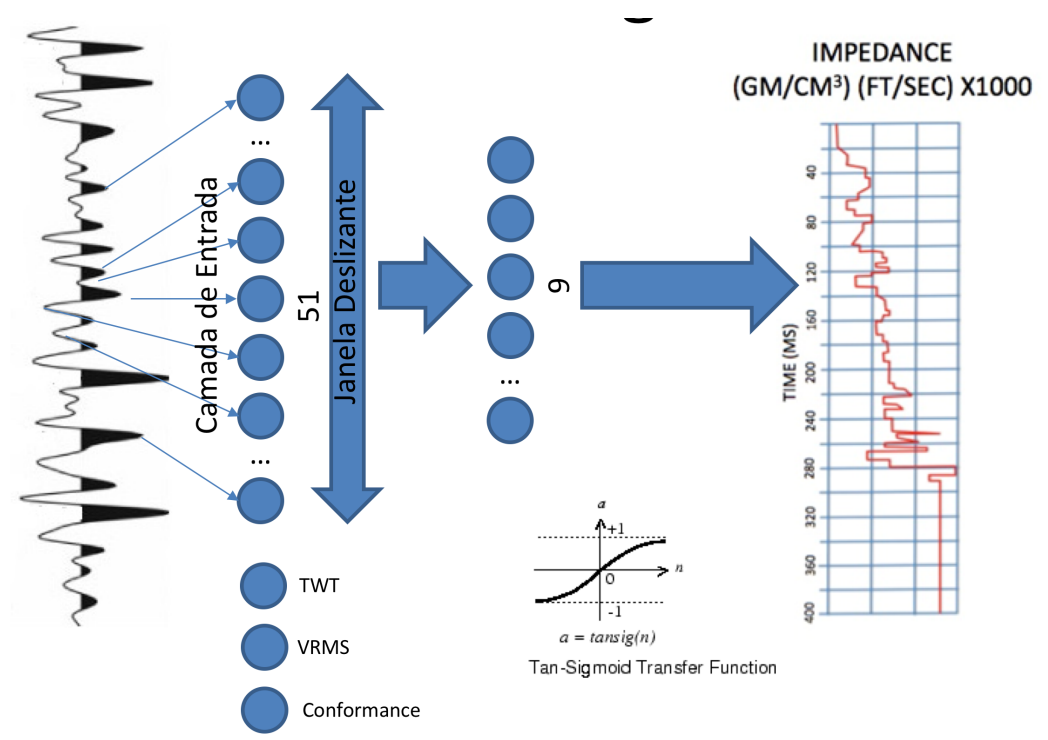

Figura 5.9: Modelagem e atributos da Rede Neural Artificial

\subsection{1}

\section{Modelagem da Rede Neural}

Partindo do trabalho de Cybenko [21], que diz que qualquer função contínua pode ser representada por uma rede neural de apenas uma camada escondida com uma função de ativação sigmoidal e no trabalho de De Groot [6], introduzido no Capítulo 4, onde a estimativa da porosidade no volume é realizada através da utilização de uma janela deslizante nos traços sísmicos, a abordagem escolhida foi o modelo da Figura 5.9.

Para se definir o número de neurônios em cada camada, o primeiro critério utilizado foi manter o número de neurônios na camada de entrada em 51, como mostrado na seção 5.2, pois assim consegue-se representar a componente linear e limitado em banda da impedância acústica. Para a camada interna, iniciou-se a pesquisa utilizando as regras conhecidas como Rules of Thumb contidas em [22], que apresenta uma heurística que propõe que camada interna deve conter 
até a metade do número de neurônios da camada de entrada, onde no caso desse trabalho é arredondado para 26 neurônios.

Com isso, ao final dessa etapa, os hiper-parâmetros da rede neural ficaram com a seguinte configuração da tabela 5.4:

\begin{tabular}{ll}
\hline \multicolumn{2}{c}{ Hiper-Parâmetros da Rede Neural } \\
\hline Função de ativação & Sigmóide - Tangente hiperbólica \\
Camadas escondidas & 1 \\
Neurônios na camada escondida & 26 \\
Medida de Performance & Erro Médio Quadrático (MSE) \\
Número máximo de épocas & 1000 \\
Estratégia de regularização & Early stopping \\
Função de treinamento & Scaled Conjugate Gradient \\
Validação & Randômica - Treinamento: 70\%, \\
& Teste: 15\%, Validação 15\% \\
\hline
\end{tabular}

Tabela 5.4: Hiper-Parâmetros do modelo inicial da Rede Neural para reprodução do algoritmo de Inversão baseada em Modelos

\subsection{2}

\section{Os Atributos Sísmicos utilizados e os Resultados}

Com a modelagem inicial da Rede Neural já definida, o passo seguinte foi escolher o melhor conjunto de atributos que pudessem ajudar na estimativa da impedância acústica.

Os atributos utilizados estão listados abaixo:

(i) Traços de amplitude sísmica;

(ii) TWT (Two-Wave Traveltime): Tempo de Trânsito duplo da onda, isto é o tempo desde a fonte até ser refletida e voltar ao receptor;

(iii) VRMS (Velocidade RMS): Modelo de velocidade usado no processamento sísmico;

(iv) Conformance: profundidade relativa entre dois horizontes;

(v) CI: Inversão Colorida.

A escolha desses atributos, ao contrário do apresentado por Kuroda [5], são atributos que não podem ser calculados somente a partir do traço sísmico, pois espera-se que a rede neural seja capaz de combinar as amostras ao longo da janela deslizante de forma a encontrar a melhor combinação não linear entre eles. 
A cada subseção seguinte do trabalho é apresentado um atributo, sendo explicado brevemente com uma imagem mostrando o resultado do algoritmo comparando-se com o valor esperado, isto é, o resultado da Inversão Baseada em Modelos. Como explicado em 5.1.1, o treinamento foi realizado na inline 425 e aplicado na inline 362. Cada um dos resultados é apresentado de forma qualitativa (visual), numericamente por meio do seu R2 Score traço a traço e em $R 2$ Score médio entre os traços. Os atributos serão incluidos incrementalmente na ordem apresentada.

\subsubsection{1}

\section{A amplitude sísmica}

A amplitude sísmica foi o primeiro atributo sísmico utilizado, sendo o mais importante, pois é onde estão as informações da refletividade como apresentado em 2.1.6 e 2.2.1. Nesse atributo utilizou-se uma janela deslizante com 51 neurônios, sendo um central e 25 anteriores e 25 posteriores como mostra a figura 5.9.

O resultado como podemos ver qualitativamente na Figura 5.10 consegue apresentar algumas estruturas de maior ou menor impedância acústica, mas além de muito ruidoso, não tem boa continuidade lateral. O mesmo pode ser verificado pelo resultado do $R 2$ Score que é de 0.37061 na Figura 5.11, resultado bastante baixo.
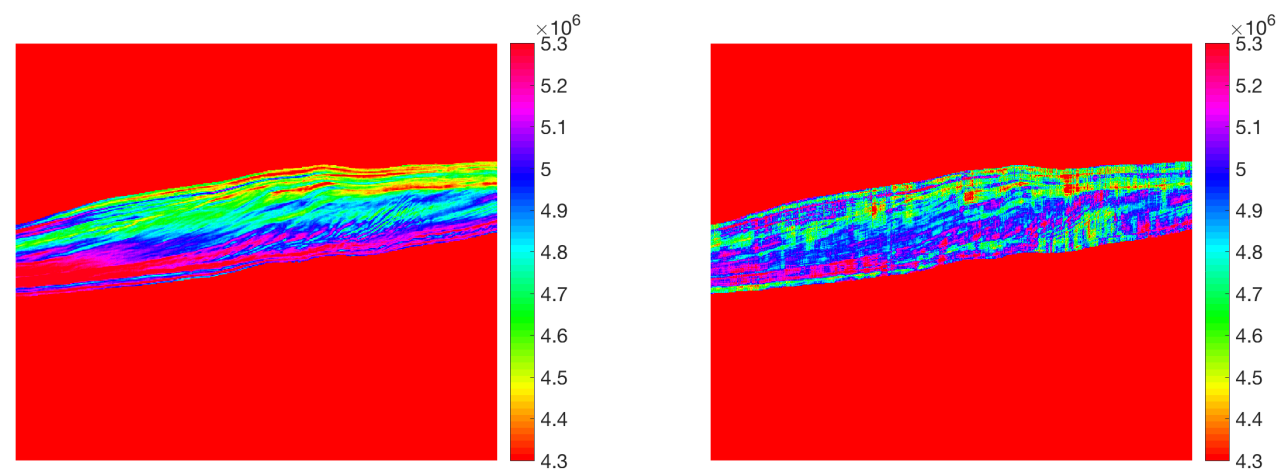

Figura 5.10: Inline 362: à esquerda o resultado da inversão baseada em modelos, e à direita o resultado do modelo utilizando apenas traços sísmicos como atributo 


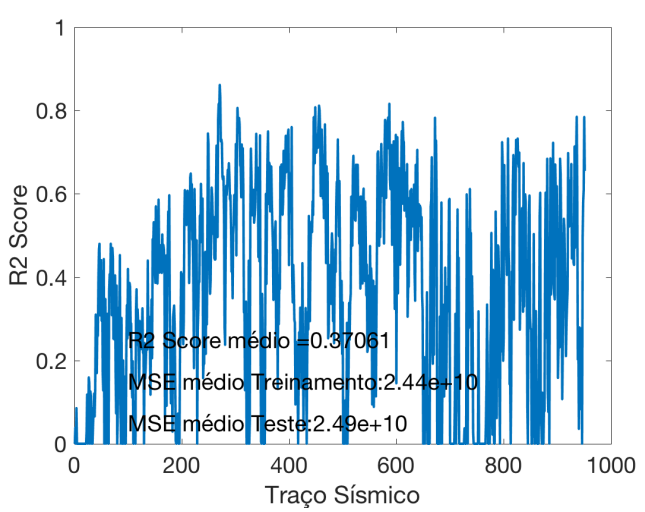

Figura 5.11: R2 Score traço a traço entre a inversão baseada em modelos e a inversão apenas com traços sísmicos como atributo

\subsubsection{2}

\section{TWT - Two Wave Traveltime}

O próximo atributo a testarmos foi o tempo duplo de trânsito da onda, que além de ter sido usado no trabalho de De Groot [6], intuitivamente acreditávamos ser um importante atributo, pelos seguintes motivos:

- A wavelet não é estacionária como explicado em 2.1.4, com isso um operador único para todas as profundidades parece inadequado;

- A lei de Faust, apresentada na seção 2.3, indica que há um aumento da velocidade com a profundidade, e a Relação de Gardner mostra que a densidade acompanha a velocidade pela equação 2-15 o que traz uma tendência de baixa frequência ao modelo.
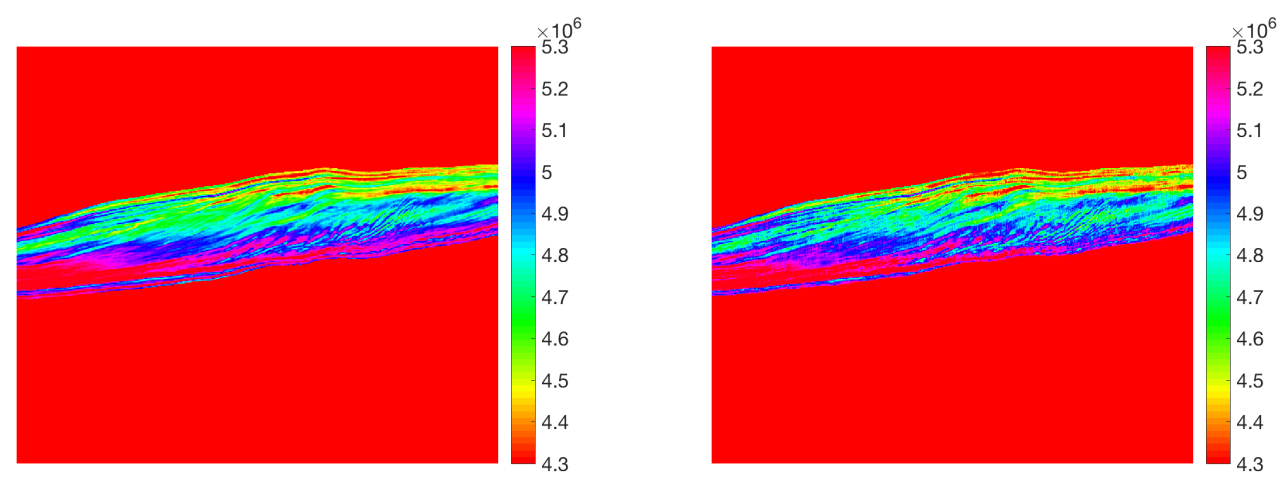

Figura 5.12: Inline 362: à esquerda o resultado da inversão baseada em modelos, e à direita o resultado do modelo utilizando traços sísmicos e tempo duplo de trânsito 


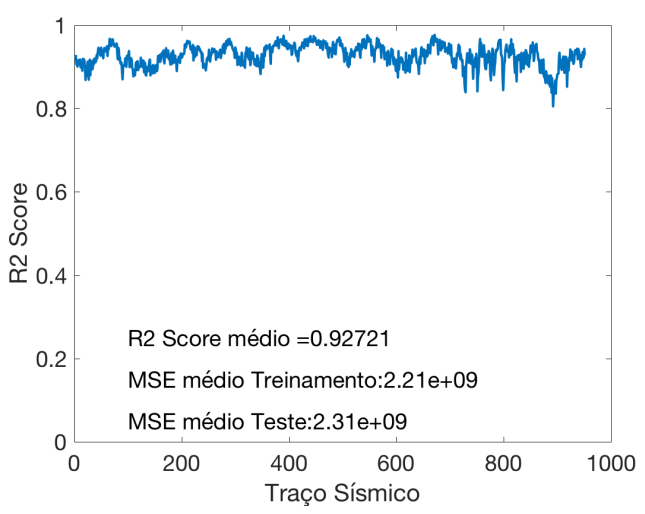

Figura 5.13: R2 Score traço a traço entre a inversão baseada em modelos e a inversão apenas com traços sísmicos como atributo

O resultado qualitativamente, como visto na figura 5.12 está bem menos ruidoso e muito semelhante à inversão baseada em modelos. Quantitativamente houve uma melhora significativa em relação à anterior, dando um R2 Score de 0.92721 que pode ser visto na Figura 5.13.

\subsubsection{3}

\section{VRMS - Modelo de Velocidade RMS}

A partir desse ponto, começamos a introduzir algumas informações geológicas ao modelo, o primeiro dado a ser testado foi o modelo de velocidade da migração sísmica (principal passo do processamento sísmico), ou também conhecido como VELAN. É um atributo importante por que traz consigo informações de propriedade de rocha (velocidade média), que pode ser associada a densidade e consequentemente a impedância. A Figura 5.14 mostra o campo de velocidade na inline 425, onde as velocidades na superfície são de aproximadamente $1500 \mathrm{~m} / \mathrm{s}$ a na região mais profunda do dado em torno de 2200 $\mathrm{m} / \mathrm{s}$.

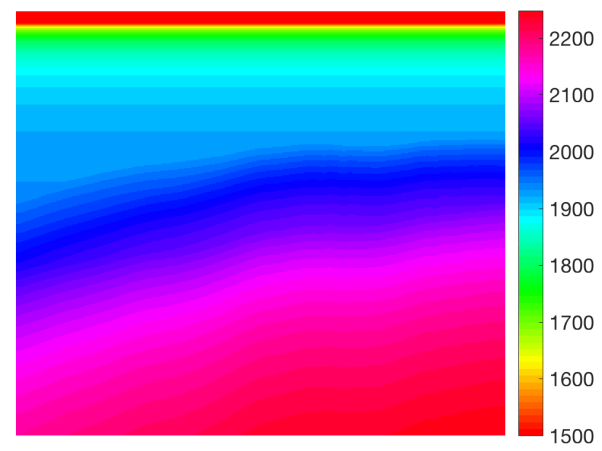

Figura 5.14: Modelo de Velocidade RMS na Inline 425 

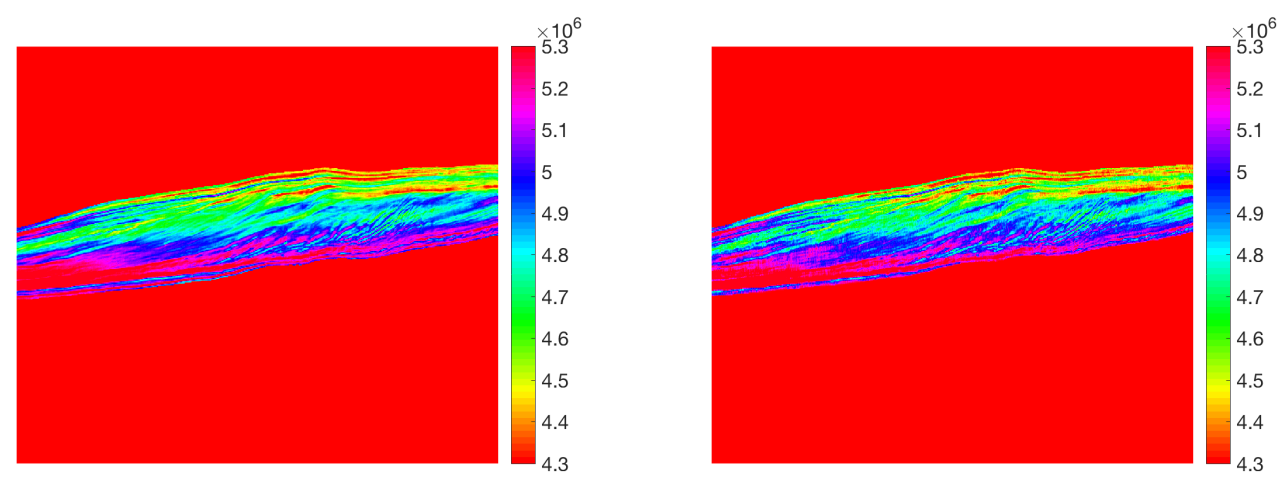

Figura 5.15: Inline 362: à esquerda o resultado da inversão baseada em modelos, e à direita o resultado do modelo utilizando traços sísmicos, tempo duplo de trânsito e modelo de velocidade RMS

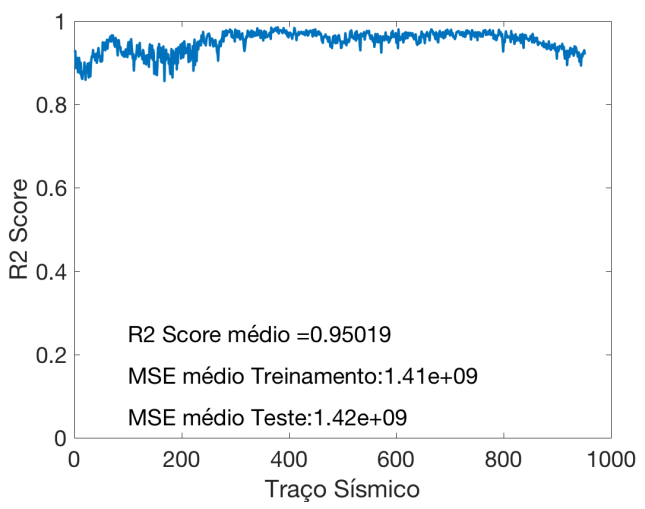

Figura 5.16: R2 Score traço a traço entre a inversão baseada em modelos e a inversão baseada em Redes Neurais com traços sísmicos, tempo duplo de trânsito e modelo de velocidade RMS

Analisando qualitativamente, é bastante difícil ver uma melhora significativa em relação ao resultado anterior quando observamos a figura 5.15, porém vê-se uma melhora significativa no R2 Score, que subiu para 0.95019.

\subsubsection{4}

\section{Conformance}

Como pode-se verificar nas figuras 5.11, 5.13 e 5.16, em todos os casos o resultado está convergindo melhor no centro do dado do que nas bordas. Isso provavelmente pode ser explicado pois como a região de interesse é inclinada e não tem a mesma espessura ao longo de todo o dado, com isso a tendência é que o algoritmo tenha melhores resultados onde a distância seja mínima aos dois extremos, nesse caso, na média.

Com o objetivo de homogeneizar o resultado ao longo de todo o dado, pode-se utilizar o atributo de Conformance Proporcional entre dois horizontes, 
pois traz informações geológicas puramente estruturais do dado e seu cálculo é extremamente simples, como podemos ver na imagem 5.17 , sendo apenas um escalar de 0 a 1 a partir do horizonte de topo até a base da região de interesse.

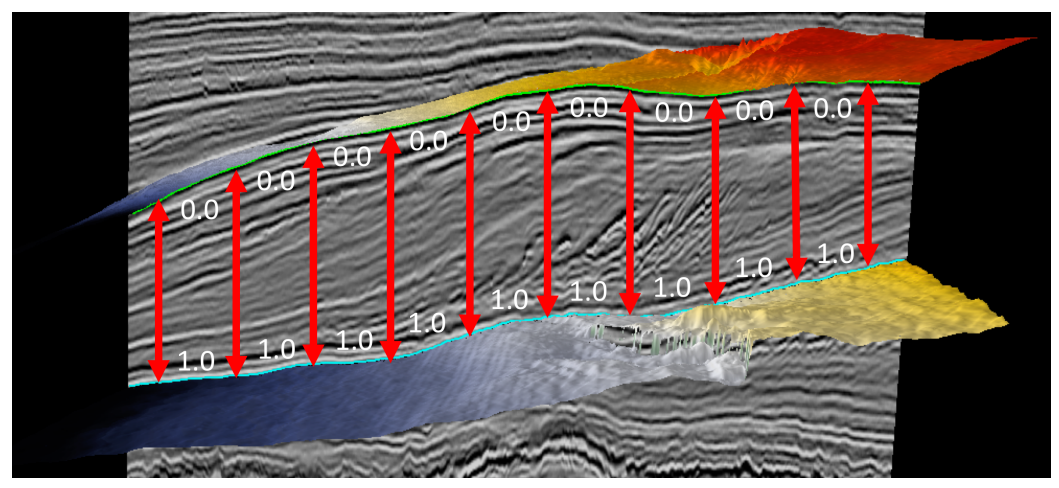

Figura 5.17: Conformance entre os dois horizontes de interesse utilizados no trabalho
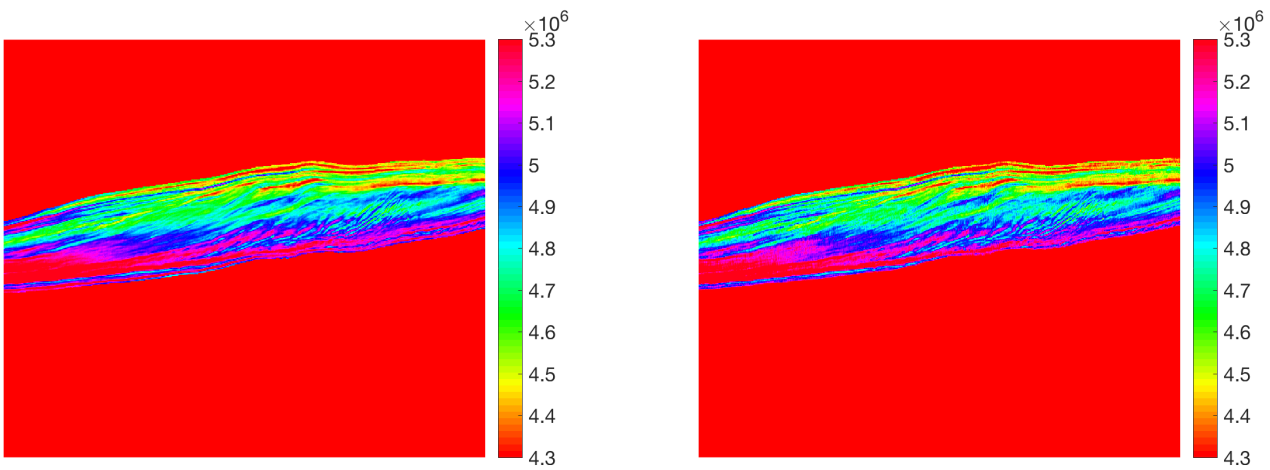

Figura 5.18: Inline 362: à esquerda o resultado da inversão baseada em modelos, e à direita o resultado do modelo utilizando traços sísmicos, tempo duplo de trânsito, modelo de velocidade RMS e Conformance

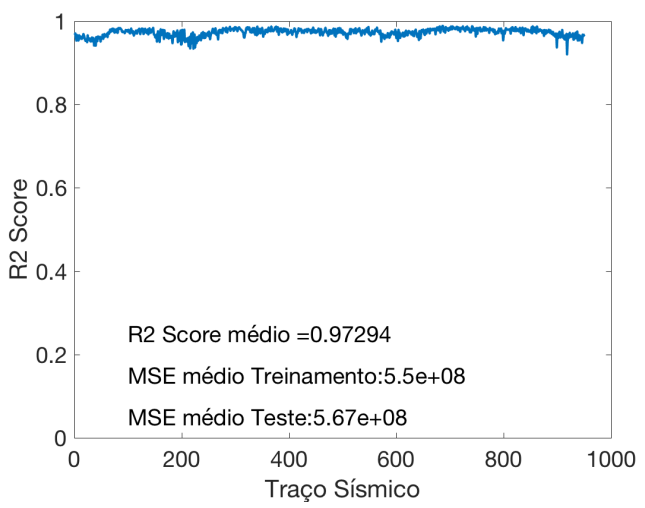

Figura 5.19: R2 Score traço a traço entre a inversão baseada em modelos e a inversão baseada em Redes Neurais com traços sísmicos, tempo duplo de trânsito, modelo de velocidade RMS e Conformance 
O resultado apresentado na figura 5.19 mostra que de fato o algoritmo convergiu igualmente ao longo de todo o dado, ficando o R2 praticamente constante em todos os traços. Visualmente observando a figura 5.18, verificase que agora a inversão baseada em modelos e a proposta são praticamente indistinguíveis e com um resultado de R2 Score bastante expressivo de 0.97294.

\subsubsection{5}

\section{CI - A Inversão Colorida}

O último atributo a ser utilizado nos experimentos foi a Inversão Colorida. A escolha da utilização desse atributo se deu por dois motivos: o primeiro pelo fato da inversão colorida trazer informações da impedância acústica do poço, que poderia fazer o algoritmo ter uma melhor convergência, uma vez que traz uma informação mais próxima da realizada; a segunda é o fato de termos esse atributo em mãos já calculado como parte do processo.
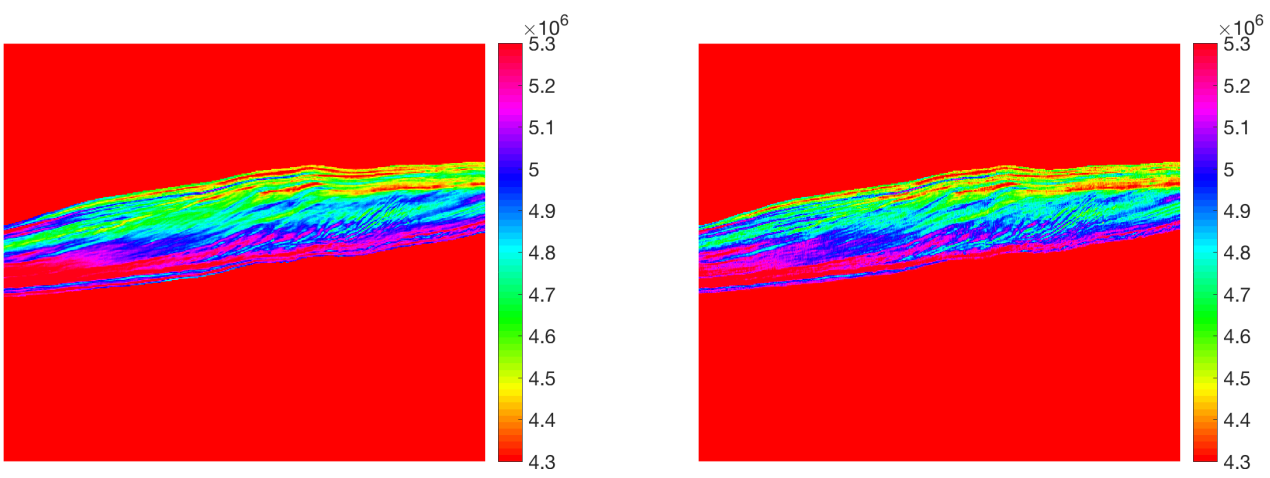

Figura 5.20: Inline 362: à esquerda o resultado da inversão baseada em modelos, e à direita o resultado do modelo utilizando traços sísmicos, tempo duplo de trânsito, modelo de velocidade RMS, Conformance e Inversão Colorida

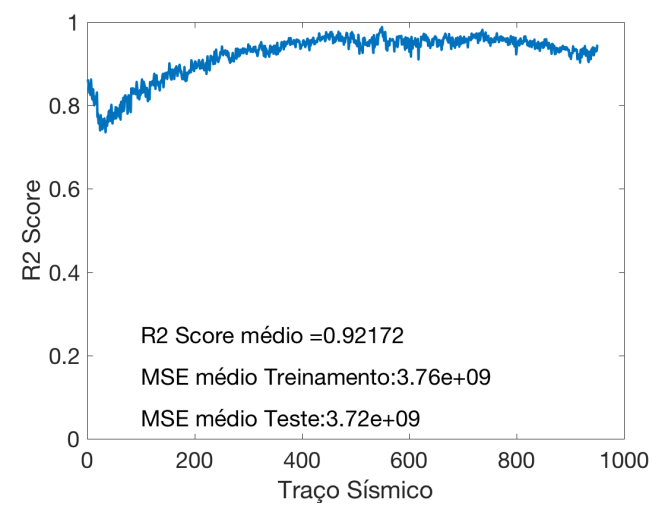

Figura 5.21: R2 Score traço a traço entre a inversão baseada em modelos e a inversão baseada em Redes Neurais com traços sísmicos, tempo duplo de trânsito, modelo de velocidade RMS, Conformance e Inversão Colorida 
Analisando os resultados de $R 2$ Score na Figura 5.21, vemos que não houve melhora em relação ao resultado da utilização do atributo de Conformance (figura 5.19), e em termos de MSE inclusive houve uma piora significativa. A razão que parece mais óbvia nesse caso é que a Wavelet Sísmica pode não ser fase zero, o que faria com que a rotação a $-90^{\circ}$ introduzida não fosse suficiente para posicionar as estruturas verticalmente em suas posições reais.

\subsection{3}

\section{O modelo final da Rede Neural}

Uma vez que os atributos estão definidos e que a modelagem inicial da rede se mostrou bastante eficaz, apenas um ajuste fino no número de neurônios na camada escondida é desejável, que apesar de ser um custo computacional muito grande testar vários modelos, a simples utilização de uma Rule of Thumb não parece uma boa estratégia.

O teste realizado foi iterar sobre o número de neurônios na camada escondida de 1 a 30, construindo o gráfico da figura 5.22, nele verificamos que apesar da configuração de 26 neurônios estar em um pico, parece que estava isolado em uma tendência de queda, como mostra a curva de tendência polinomial, e o ponto de máximo parece ser com 9 neurônios na camada escondida. Como o tempo de treinamento de cada modelo é muito grande, e na prática o número a variação de um ou dois neurônios na camada escondida não tem um efeito muito grande nos resultados, a estratégia escolhida for executar uma única vez com cada configuração e ao final aproximar a curva por uma polinomial de quarta ordem, gerando a curva pontilhada na Figura 5.22.

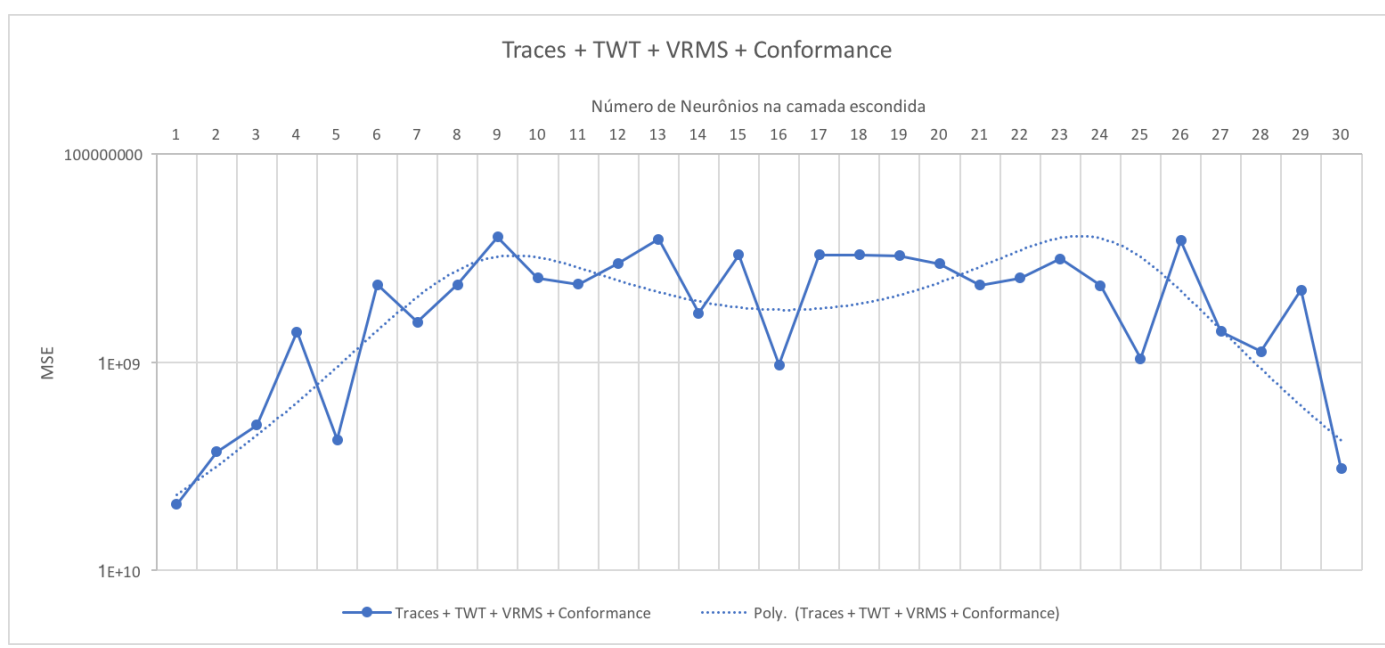

Figura 5.22: MSE por número de neurônios

Os resultados da inversão ficaram marginalmente melhores à configuração anterior, tendo um R2 Score de 0.97893 (figura 5.24), mas considerando 
que é uma modelagem mais simples, menos suscetível a overfitting, menor custo computacional e necessidade de um número menor de exemplos para o treinamento, a escolha por 9 neurônios na camada escondida parece mais adequada.
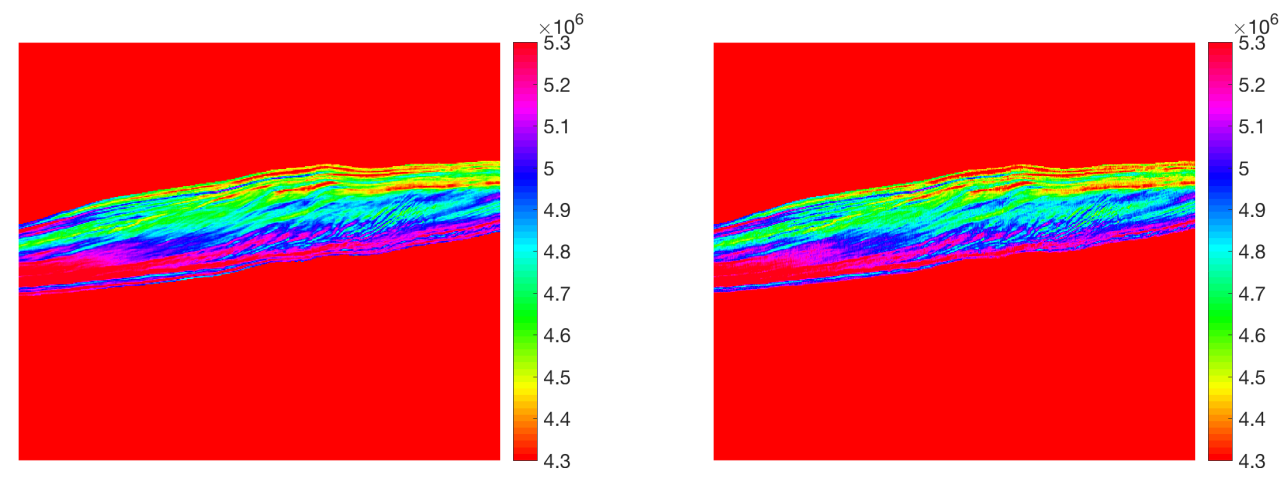

Figura 5.23: Inline 362: à esquerda o resultado da inversão baseada em modelos, e à direita o resultado do modelo final utilizando traços sísmicos, tempo duplo de trânsito, modelo de velocidade RMS e Conformance

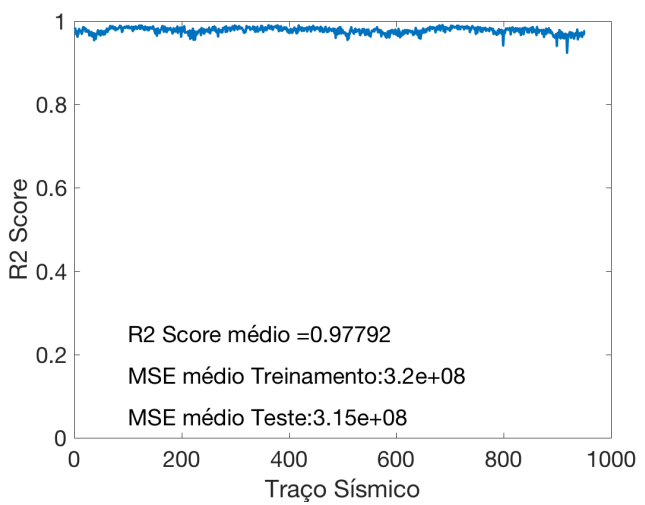

Figura 5.24: R2 Score traço a traço entre a inversão baseada em modelos e a inversão baseada em Redes Neurais com traços sísmicos, tempo duplo de trânsito, modelo de velocidade RMS e Conformance

Ao final, a modelagem da rede neural, assim como seus hiper-parâmetros e os atributos necessários estão resumidos na Figura 5.9 e na tabela 5.5. 


\begin{tabular}{ll}
\hline \multicolumn{2}{c}{ Hiper-Parâmetros da Rede Neural } \\
\hline Função de ativação & Sigmóide - Tangente hiperbólica \\
Camadas escondidas & $\left.1 \frac{2}{1+e^{-2 n}}-1\right)$ \\
Neurônios na camada escondida & 9 \\
Medida de Performance & Erro Médio Quadrático (MSE) \\
Número máximo de épocas & 1000 \\
Estratégia de regularização & Early stopping \\
Função de treinamento & Scaled Conjugate Gradient \\
Validação & Randômica - Treinamento: 70\%, \\
& Teste: 15\%, Validação 15\% \\
\hline
\end{tabular}

Tabela 5.5: Hiper-Parâmetros do modelo final da Rede Neural para reprodução do algoritmo de Inversão baseada em Modelos 


\section{6 \\ Conclusões e trabalhos futuros}

Como conclusão do trabalho, chegamos que a inversão sísmica acústica determinística pode ser representada por meio de uma rede neural multilayer perceptron com apenas uma camada escondida e um conjunto simples de atributos sísmicos.

Contudo, a grande vantagem percebida nessa abordagem é a simplicidade, pois uma vez que se tenha um conjunto de dados de amostras suficientes, praticamente nenhuma modelagem é necessária e com isso um profissional não-especialista em inversão sísmica consegue realizar a operação.

Existem vários trabalhos futuros para esse, inclusive alguns estão em fase avançada de desenvolvimento, pode-se citar:

- Teste não somente no reservatório, mas também em overburden.

- Utilização de dados pre-empilhamento ou de empilhamento parcial;

- Implementação da Inversão elástica;

- Predição de outros atributos de rocha além da impedância acústica;

- Testes com dados em profundidade;

- Data Augmentation nos dados em torno do poço para aumentar o número de amostras necessárias para treinamento;

- Utilização de outras técnicas para diminuir o número de amostras necessárias, como uma Neural Turing Machine ou uma Rede Neural Probabilística pode ser eficaz;

Alguns desses teriam objetivo de enriquecer mais os resultados, outros de encurtar o trabalho de análise e modelagem necessária. Sendo que a maior parte por si só seriam produtos isolados merecendo uma pesquisa específica. 


\section{Referências bibliográficas}

[1] BROWN, A. R. AAPG Memoir 42 and SEG Investigations in Geophysics, No. 9, Chapter 1: Introduction. American Association of Petroleum Geologists, 2004.

[2] OLDENBURG, D. W.; SCHEUER, T.;LEVY, S. Recovery of the acoustic impedance from reflection seismograms. Geophysics, 48(10):13181337, 1983.

[3] LEITE, E. P. Seismic model based inversion using matlab. MatlabModelling, Programming and Simulations, 1:405-412, 2010.

[4] LANCASTER, S.; WHITCOMBE, D. Fast-track 'coloured' inversion. In: SEG TECHNICAL PROGRAM EXPANDED ABSTRACTS 2000, p. 15721575. Society of Exploration Geophysicists, 2000.

[5] KURODA, M. C.; VIDAL, A. C.; PAPA, J. P. Analysis of porosity, stratigraphy, and structural delineation of a brazilian carbonate field by machine learning techniques: A case study. Interpretation, 4(3):T347-T358, 2016.

[6] DE GROOT, PAUL F. M. Seismic reservoir characterisation using artificial neural networks. 1999.

[7] MISRA, S.; CHOPRA, S. Neural network analysis and impedance inversion-case study. Recorder, 2011.

[8] PORTUGAL, R. Fundamentos Matemáticos para Geofísica I Funções de uma Variável. Blucher, 2012.

[9] CHOPRA, S.; MARFURT, K. J. Seismic attributes for prospect identification and reservoir characterization, volumen 11 . Society of Exploration Geophysicists Tulsa, Oklahoma, 2007.

[10] SILVA, J. Apostila da Disciplina de Introdução ao Método Sísmico. Universidade Federal do Rio de Janeiro, Março 2013.

[11] MAVKO, G.; MUKERJI, T.; DVORKIN, J. The rock physics handbook: Tools for seismic analysis of porous media. Cambridge university press, 2009. 
[12] SHERIFF, R. E. Aspects of seismic resolution: Chapter 1. AAPG Special Volumes, 1985.

[13] RUSSELL, B. H. Introduction to seismic inversion methods. Society of Exploration Geophysicists, 1988.

[14] FAUST, L. Y. Seismic velocity as a function of depth and geologic time. Geophysics, 16(2):192-206, 1951.

[15] GARDNER, G. H. F.; GARDNER, L. W.; GREGORY, A. R. Formation velocity and density - the diagnostic basics for stratigraphic traps. Geophysics, 39(6):770-780, 1974.

[16] SEN, M. K.; STOFFA, P. L. Global optimization methods in geophysical inversion. Cambridge University Press, 2013.

[17] MA, X.-Q. A practical workflow for model-driven seismic inversion. First Break, 35(5):39-44, 2017.

[18] OPPENHEIM, A. V.; WILLSKY, A. S.; NAWAB, S. H. Signals and systems, second edition. Prentice-Hall, 1996.

[19] HAMPSON, D. P,; SCHUELKE, J. S.; QUIREIN, J. A. Use of multiattribute transforms to predict log properties from seismic data. Geophysics, 66(1):220-236, 2001.

[20] NERY, GERALDO G. Perfilagem Geofísica em Poço Aberto: Fundamentos básicos com ênfase em petróleo. Socidedade Brasileira de Geofísica, Rio de Janeiro, 2013.

[21] GYBENKO, G. Approximation by superposition of sigmoidal functions. Mathematics of Control, Signals and Systems, 2(4):303-314, 1989.

[22] PRIDDY, K. L.; KELLER, P. E. Artificial neural networks: an introduction, volumen 68. SPIE press, 2005. 